\title{
Critical Analysis of Lasuna (Role of Lasuna in Different Branches of Ayurveda)
}

\author{
Dr. Rajimunnisa Begam Shaik. M.D (Ayu) ${ }^{1}$ Dr. D. R. Sunil Kumar ${ }^{2}$ \\ Dr. S. Ramalingeswara Rao M.D (Ayu) ${ }^{3}$ Dr. J.Srinivasulu M.D (Ayu $)^{4}$ \\ ${ }^{1}$ J.R.F. CCRAS.VIJAYAWADA, ${ }^{2}$ M.D. First Year,P.G.Department of K.C \\ ${ }^{3}$ Associate professor P.G. Dept.of Kayachikitsa, ${ }^{4}$ Professor \& H.O.D P.G. Dept.of Kayachikitsa \\ Dr.B.R.K.R.Govt.Ayurvedic Medical College, Hyderabad
}

\section{Introduction}

Garlic, Allium sativum L. is a member of the Liliaceae family, which has been widely recognized as a valuable spice and a popular remedy for various ailments and physiological disorders. The name garlic may have originated from the Celtic word 'all' meaning pungent. Cultivated practically throughout the world, garlic appears to have originated in central Asia and then spread to China, the Near East, and the Mediterranean region before moving west to Central and Southern Europe, Northern Africa (Egypt) and Mexico.Hippocrates, the father of medicine, had mentioned Lasuna in his medical notes and recommended its use in treating infections. Lasuna was known to Chinese health providers before 3,000 BC and is a vital part of the Chinese diet and medicine even today. It also features strongly in Egyptian, Greek, Roman and African diets and is used as a medicine for several common ailments.Garlic has been used for thousands of years for medicinal purposes. Sanskrit records show its medicinal use about 5,000 years ago, and it has been used for at least 3,000 years in Chinese medicine. The Egyptians, Babylonians, Greeks, and Romans used garlic for healing purposes. In 1858, Pasteur noted garlic's antibacterial activity, and it was used as an antiseptic to prevent gangrene during World War I and World War II. Garlic's current principal medicinal uses are to prevent and treat cardiovascular disease by lowering blood pressure and cholesterol, as an antimicrobial, and as a preventive agent for cancer. The active constituents are several complex sulfur-containing compounds that are rapidly absorbed, transformed and metabolized. Pooled data from numerous randomized trials suggest that garlic lowers total cholesterol concentrations by approximately $10 \%$ and favorably alters HDL/LDL ratios. Randomized trials also support garlic's effectiveness as a mild antihypertensive which lowers blood pressure by 5-7\%. Garlic also inhibits platelet aggregation and enhances fibrinolytic activity, reducing clots on damaged endothelium. In vitro data suggest antibacterial effects, but these have not been evaluated in controlled trials in humans. Ayurveda, the eternal science of life, has been catering to the need of mankind since centuries with its immense treasure of potentially useful sources of drugs in not only treatimg the diseases but also preventing the diseases. The complete knowledge of the drugs with respect to its characters and pharmacological actions is very much necessary to combat the ailments that occur in the human body from time to time. Ayurvedic pharmacology unravels different aspects like drug delivery form, dose, mechanism of action; time of action metabolism etc.

Knowledge of medicinal uses of single drugs in treating the disease with scientific approach is the need of the hour, when manufacturing of poly-herbal preparations is causing an alarming situation in depletion of our natural resources. Ayurveda has put forth many principles with respect to different lifestyles that are to be adopted for sustenance of health among the humankind. Unfortunately, with changing times, the lifestyles have also changed enormously resulting in ill health.A single herb Lasuna which is used in our daily culinary is a wonderful drug which is used as medicine in treating vata vyadhis (i.e. Neuro endocrinal, immunological systems of the body). It is having katu pradhana amla varjita pancha rasa (madhura, katu, thiktha, kashaya, lavana rasas) with gunas like Snigdha, Ushna, Sara, Guru, Teekshna, Picchila and Ushna veerya and Katu vipaka and Vata Kaphahara property. It is mentioned as pathya in vata vyadhis. It is considered as best for treating vata vikaras and in all types of Avarana. Lasuna has got anti-inflammatory, anti-oxidant, analgesic, antithrombotic, fibrinolytic activity, which has initiated this work.

\section{Historical Reveiw Of Lasuna}

- We get references regarding Lasuna in Vaikhanasa dharmashastra, Varahadharmashastra and Samaanthu dharmashastra.

- Lashuna is mentioned under Vanoushadi Varga in Amarakosha.

- Lashuna finds its place in almost all Ayurvedic texts. i.e. in Bruhatrayees, Laghutrayees and in all Nighantus.

- Lasuna is described in Atharva Parisishta. 
1. The history of Lasuna (Allium sativum. linn) dates back to 4500 B.C as described by Lloyd. Harris in the book of Garlic. It was used in China, Egypt and by Buddist Monks as medicine for various ailments. It came into use in India only 200years later. Mostly foreign invaders brought this drug to India hence it has the name Mlechakandaa.

2. The use of Lasuna as food stuff was considered as unholy, we get references from Mahabharatha that Lasuna was not used by respected persons of the society. In the later period people started using Lasuna as a food stuff considering its medicinal Properties, May be because of its persistent odour, and its effect on the opposite person. (Indians respect one \& all)

3. Ayurvedic literature like Charaka, Sushrutha,Kashyapa and Vagbhata indicate Lasuna as a useful medicine and food. The later works like Nighantus also describes the utility of Lasuna as food and medicine.

4. Lashuna has been used by Brihatrayee's extensively in the treatment of Vataroga Chikitsa and as Rasayana but it is not included in any of their Ganas or Vargas.

\section{Mythology}

The stories revealing the origin of Lasuna:-

1. When Indrani did not become Garbhavathi even after 100 years, Indra administered Amrutha to drink holding her closely and giving santhvana. Sukumari Indrani has attained amruthasara and in presence of pathi she had lajja and also got udgara by which Amrutha fell down to the earth in apavithra sthana. During which Indra told Indrani that she will have Bahuputras so only Lashuna is having more number of cloves and rasayana karma. But due to sthanadosha, it is having durgandha and is not been used by Dwijas. The Amrutha which has fallen existed on the earth in the form of Lashuna (Kashyapa -kalpa 7/12.)

2. When Amrutha got stolen and drunk by Rahu, Bhagavan Vishnu cut his neck with chakra, the head fell down along with neck on earth, during which Amruthakana fell on Earth and exist as Lashuna. Since Amrutha has got sparsha with shareera of daitya, it has got durgandha and is similar to Amrutha and best Rasayana. (Gadha Nigraha 2/212.)

3. Amrutha apaharan was done by the rakshasa Rahu, during which a drop of Amrutha was fallen on earth due to a hole in neck while drinking, by which Lashuna came to the earth. Since it is derived from Daityadeha, dwijas do not eat Lashuna. It is considered as equal to Amrutha and Rasayana by grameena jana. (A H Uttara 39/111-112.)

4. There is a story in Puranas and Nighantus that when garuda, the lord of birds stole Amrutha from Indra in heaven, some drops of Amrutha fall on earth. These drops are said to have formed into Lasuna (BP 11/218.)

\section{Evolution:-}

Garlic is a cultivated plant and is thought to have originated in the central Asian mountain regions as onions. The nearest wild relative is Allium longicurpis, which is still grown in this region. Garlic is generally regarded as a sterile species which is propagated only vegetatively by multiplication of planted cloves. However recently some fertile seed producing cloves have been collected in the Tein shan mountains in Kirgizia and western china (Etoh 1986). Garlic cloves that exist are adapted to many ecological zones through their response of growth and bulbing to temperature and photo period, their cold hardness and duration of bulb dormancy. (Takagi 1990). Diversity also exists in size of cloves their number, bulb weight, colour and number of outer skins size and vigour of the foliage, and the comparison of wide range of cloves growing in a standard environment. Jone \& Mann (1963) concluded that there was no justification of using some of the species they suggested the name Rocamble" might be applied to the wild species, Allium scordosasum. This has occasionally been so named and it has been used for food but it is not cultivated (John Parry species vol 1 1969).

\section{Dravyaguna Aspects Of Lasuna}

Botanical name : Allium sativum

Family : Liliaceae

\section{Vernacular Names:}

\begin{tabular}{|c|c|}
\hline Arabic & saum, Taum \\
\hline Assam & Naharu \\
\hline Bengal & Lashan, Lashun, Rasun \\
\hline Bhote & Gkpas \\
\hline
\end{tabular}




\begin{tabular}{|c|c|}
\hline Bombay & Luson \\
\hline Burma & Kesumphin, kyathou \\
\hline Bhutan & Gokapas \\
\hline Cambodia & Kancchai \\
\hline Canarese & Belllulli \\
\hline Catalan & All \\
\hline Chinese & Suan, Tasuan \\
\hline Deccan & Shunam \\
\hline Dutch & Knoflook \\
\hline English & Garlic, Poormans tracle \\
\hline French & Ail, AIlcommum \\
\hline German & knobluch \\
\hline Greek & Aglidion \\
\hline Gujarathi & Lasan \\
\hline Hamsa & ta farmuwa \\
\hline Hindi & Lashan, Lasan \\
\hline Hova & Tongolugasy \\
\hline Italian & Aglio \\
\hline Jolo & Bauang poti \\
\hline Kannada & Bellulli \\
\hline Konkani & Lashun \\
\hline Latin & Allium Sativum \\
\hline Malayalam & Vellulli, Veluthulli \\
\hline Malaya & Dawang Lasuna \\
\hline Marathi & Lashun, paridari Tambudi \\
\hline Persian & Sir, Seen. \\
\hline Portuguese & Altho, Alho \\
\hline Punjab & Thumo \\
\hline Romania & Aiu \\
\hline Russian & Chernok \\
\hline Sanskrit & Lashuna, Rasona \\
\hline Tamil & Vellaipandu \\
\hline Telugu & Vellulli, tellagadda \\
\hline Tulu & Bollulli \\
\hline Turki & Sansak \\
\hline Unani & Skordon \\
\hline Urdu & Lehsun \\
\hline
\end{tabular}

\section{Synonyms:}

- Ugragandha

- Yavanesta

- Rason

- Mahousadha

- Mlechakandaa

Varieties:-Lashuna is of 2 types according to Kashyapa:

1. Girija (Allium Ursinum) - it is said to be Amrutha samana

2. Kshetraja (Allium sativum) - In the absence of Girija Lashuna, kshetraja Lashuna prayoga is done (Kashyapa samhita Lashuna kalpa 114)

\section{According to Kaiyyadeva Nighantu Rasona is of 3 varities}

\section{Grunjanaka}

2. Mahakanda 
3. Garjara

According to Raja nighantu Ratnakara Rasona is of $\mathbf{3}$ types and mentioned varied gunas and karmas of these varities.

1. Shwetha Rasona

2. Grunjana

3. Raktha rasona

He also explained mahaskanda rasona in which leaves fall off by its own. That is Allium Ascolonicum linn. It is called as Gandana.

\section{There are 2 varities of Garlic which are world famous}

1. Pahvri

2. Rajalle - (S.C Kubha sadha, Masala belegalu 198)

\section{3 varieties of Lashuna has been identified}

1. Laghu Rasona - leaves and roots are small

2. Maha Rasona - leaves and roots are large

3. Grinjanaka - yellow in colour and it is sweet- Aswatha narayana 1966.

\section{Habit:-}

1. Allium $=$ Garlic, sativum $=$ Cultivated

2. Allium sativum is a scapigerous foetid perennial herb with underground compound bulbs small leaves flat, narrow, bulbs white to pink in colour, characterstic of aromatic odour, pungent taste, about 1.5-2.5 cms size (Flora of British India, T.D Hooker.)

3. Flower Capitate/Umbellate, white all at first enclosed in 1-3 membranous spathes, stellate or campunulate, sepals-6, free/connate below, stamens hypogynous or inserted on the perianth: filaments free/connate below, anthers ablong, ovary 3-gonous, 3-celled, style filiform, stigma minute, cells few ovuled capsules small locolicidal, seeds few, compressed testa black, species 325-N-hemisphere (Kirthikar and basu vol 4 1975).

Taxonomical Classification:

\section{Taxonomical classification of Lasuna}

\begin{tabular}{|l|l|}
\hline Kingdom & Plant kingdom \\
\hline Division & Phenerograms \\
\hline Subdivision & Angiosperms \\
\hline Class & Monocotyledons \\
\hline Natural order & Liliaceae \\
\hline Subfamily & Alliocidae \\
\hline Tribul & Allieceae \\
\hline Genes & Allium \\
\hline Species & Sativum \\
\hline
\end{tabular}

\section{Morphology:-}

1. Lashuna is a hardly perennial herb with narrow flat leaves and bears small white flowers and bulbils. It is a sub globular compound bulb surrounded by a few dry membranous scales which cover the remnant of the upright stem and 5-8 small bulbs arranged in a circle around its base. The bulb consists ofseveral smaller cloves enclosed in a silky white or pink envelop of the skin, these bulb lets are oblong in outline, compressed from both sides, wedge shaped towards the stem and rounded upon the back.

2. They consists of few thick fleshy scales and a short fleshy axis stem is simple about 2 feet in height, leaves are long flat acute, sheath in the lower half of the stem, scalp smooth and shining, solid terminated by a membranous pointed spathe enclosing a mass of flowers and solid bulbils and prolonged into a leafy points.

\section{Leaves, Stem And Root:}

The plant is $25-70 \mathrm{cms}$ height with an erect, rigid or crook like stem, which is leafy in the middle. The leaves are flat, $4-25 \mathrm{~mm}$ broad linear, rough or smooth edged with a wedge shaped tip. The sheath shaped tip. The sheath is beaked and longer than the inflorescence. The garlic bulb is usually a compound bulb, secondary bulbs are ovate. The bulb is silky white or green.

\section{Flower And Fruit:-}

The long pediceled flowers have a cyme with few florets. The flowers usually remain in bud form often do not produce any seed. The petals are reddish or greenish white and longer than the stamen. The anthers of 
the middle stamen are spread at the base and have fan shaped tips. - PDR for Herbal medicine Ist Edition.

Flower - Regular, bisexual and hypogynous solitary or in spike, raceme or panicle.

Perianth - petaloid usually 6 segments in 2 whorls, usually free (polyphyllous), sometimes united (gamophyllous), Androceium-stamens-6, intwo whorls, rarely 3 hypogynous free or united with the perianth ( epiphyllous)- Gynoecium - carpels(3), syncarpus - ovary, 3-celled, ovules usually placentation axile.

Fruit - A berry or capsule

Seed - Albinous

Floral Formula - $\mathrm{O}+\mathrm{P} 3+3 \mathrm{~A} 3+3 \mathrm{G}(3)$ or $\mathrm{P}(3+3) \mathrm{A}(3+3) \mathrm{G} 3$

Identifying Characters:- (Jones and Mann 1963).

Species - Allium sativum

Diploid - Chromosomes number -16

Storage organ - Swollen, bladeless sheaths (cloves), no storage in foliage leaf bases. Time of flowering Spring Order of opening of florets in umbel - Irregular Bulbil in inflorescence - Always present

\section{Identification Of Lashuna As Per The Classics:}

It looks like kukkutanda samana in greeshma ruthu with shithila panna. It is collected by putavidhi and bandhana is done for guptha dharana by buddhiman purusha. (Haritha samhitha 5/16)

\section{Habitat}

1. Central Asia is considered to be the region of origin introduced to the mediteranean: cultivated worldwide.

2. Allium sativum Linn is very commonly found all over India. Not only does it grow wild but it is also extensively cultivated on account of its use as a spices.

3. It can be grown under a wide range of climatic conditions but it grows well in mild climate without extremes of heat and cold. It grows at altitude of $600-900 \mathrm{~m}$. A cool and humid period during growth and relatively dry period during maturation are best for cultivation of Lashuna. It can be grown on a wide variety of soils. It is cultivated in garden land and wetlands. It requires a rich well drained clay land to grow well ( The wealth of India vol 1)

4. Lashuna is cultivated in central Asia, south Europe, USA and India. In India it is found in almost all states and cultivated as spice or a condiment crop.

Family Key Features - Liliaceae:

1. Herbs, rarely shrubs or small trees with fibrous roots or with a creeping root stock or a bulb or corm leaves cauline or radical.

2. Flowers usually bi sexual, axillary or terminal, solitary or germinate or arranged in umbels, spikes, racemes, panicles or fascicles, bracts usually small, scarious or spathe like when the flowers are in umbels.

3. Merous perianth herbaceous or petaloid usually 6 in 2 series, rarely 4 or 8 or 10 merous, imbricate or rarely valvate in bud. Stamens 6 , rarely 3 or fewer hypogynous or adnate to the perianth. Filaments free or connate anthers oblong or linear often dorsifixed.

4. Ovary 3 celled, usually simple, often long, rarely short on none or with 3 styles; ovules 2 or more on the inner angles of the cells, anatropous, rarely arthothropous.

5. Fruit a capsules or berry, usually 3 celled. Seeds 1 or more, glabrous or flattened; embryo small, terete, surrounded by the honey or fleshy albumen, species about 2500 in all climate and countries. (douthie J.F flora of the upper gangetic plain256-257).

\section{Medicinal Plants of Liliaceae}

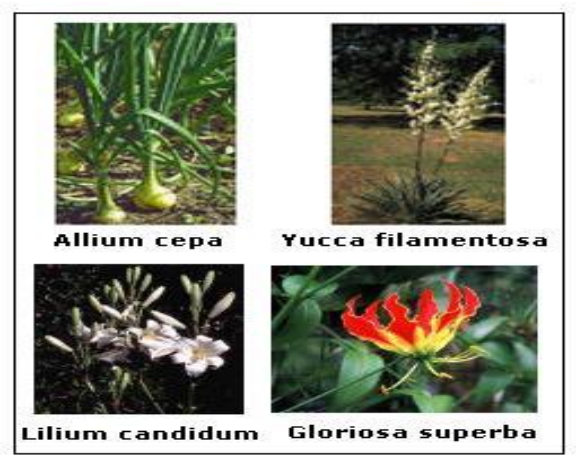




\section{Photographs of Lasuna plant:}
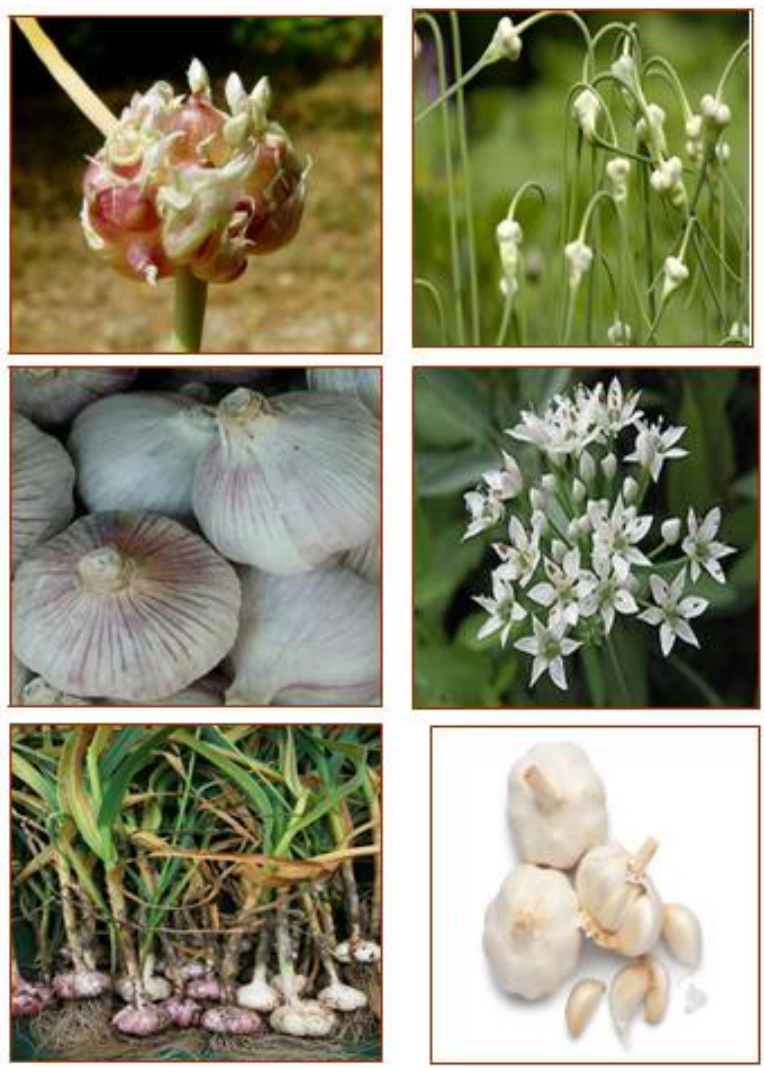

\section{Pharmacognosy}

Garlic is the compound bulb of Allium sativum Linn, a perennial plant belonging to the liliaceae or lily family. It is Indigenous to Europe and enjoys almost universal cultivation. The compound bulb consists of number of wedge shaped bulblets, often called cloves. The leaves of the garlic plant are long, narrow, flat and sheath. The flowers are purple in colour and produced in a cluster at the termination of the stem. (John p parry spices vol-1, 1969)

\section{Botanical Description:}

It is a scapigenous foetid perennial herb with underground compound bulbs.

1. Leaves - Long, flat, acute, sheathing the lower half of the stem.

2. Stem - Simple, 2 feet in height.

3. Flower - Capitates/umbellate, white, all at fiest enclosed in 1-3 membranous spathes, stellate or campanulate.

4. Sepals -6 free/ connate below

5. Stamens - Hypogynous or inserted on the perianth.

6. Filament - Free/connate below, anthers oblong.

7. Ovary -3 gynous, 3 celled, style fileform, stigma minute, cells few ovuled

8. capsule small, loculicidal.

9. Bulbs - White to pink in colour, about $1.5-2.5 \mathrm{~cm}$ in size.

10. Seeds - Few, compressed, testa black.

\section{Vargeekarana:-}

Classification of a medicinal plant is necessary to identify it and to confirm about it. Lashuna belongs to Haritha varga.

\section{Classical vargeekarana of Lasuna}

\begin{tabular}{|l|l|}
\hline AUTHOR & VARGA \\
\hline 1. Bhavamishra & Haritakyadivarga \\
\hline 2. Bapalal & Lashunadi varga \\
\hline 3. Charaka & $\begin{array}{l}\text { Shirovirechanavarga haritavarga,Bahirparimarjana } \\
\text { varga, KatuSkanda }\end{array}$ \\
\hline 4. Dhanwanthari & Karaveeradi varga \\
\hline
\end{tabular}




\begin{tabular}{|l|l|}
\hline 5. Kaiyyadeva & Aashachi varga \\
\hline 6. Madanapala & Shaka varga \\
\hline 7. Narahari pandith & Karaveeradi varga \\
\hline 8. Raja vallabha & Hingwadinam gana \\
\hline 9. Shodala & Karaveeradi varga \\
\hline 10. Sushrutha & Shirovirechan,Shaka varga,katurasavarga dravya \\
\hline 11. Vagbhata & Shaka varga \\
\hline 12. Raja Nighantu & Moolakadi varga \\
\hline 13. Priya Nighantu & Shatapushpadi varga \\
\hline 14. Amarakosha & Vanoushadi varga \\
\hline 15. Prayogatmaka Abhinava & Rasonadi varga. \\
\hline
\end{tabular}

Vargeekarana is done on the basis of specific characters, such as it's place in various country \& its effect on various signs, symptoms \& systems.

\section{Substitute And Adulterant:-}

- Bulbs of Allium Ampeloprasm Linn, which are larger in size and have 2-4 cloves, are considered a good substitute for medicinal use in some part of North India. A single clove variety of Allium Sativum grown in Rajasthan is considered more potent drug. (Sareine Illustrated manual of Herbal drugs used in Ayurveda).

- Allium porrum Linn is used as Substitute for the true Garlic. (Database $6^{\text {th }}$ volume.)

- Allium ascolonicum is used instead of Allium sativum

\section{Phytochemistry:}

- The active principle of garlic is an acid volatile oil, starch, mucilage, albumen, sugar etc. volatile essential oil $(0.25 \%)$ obtained by distilling the bruised bulbs contain allyl, propyl disulphide and other organic sulphides or sulphur compounds. It is a clear limpiol liquid of dark brown or yellow colour of very repulsive and intense garlic and of repugnant taste.

- The yield is from $0.06 \%$ to $0.1 \%$ its specific gravity at 14.5 is 1.0525 and it is optically inactive when purified. It is colorless and can be distilled without decomposition with some samples, even at winter temperature, the oil becomes semisolid through the deposition of fine crystals.

- Semler found that the oil decomposes when heated at $150^{\circ} \mathrm{c}$.

Fractionated under 16mm pressure, 4 different fractions were obtained.

1. Fraction I $(6 \%)$ - consists of allyl propyl disulphide. It has the odour of onions and gives a voluminous precipitate with mercuric chloride.

2. Fraction II $(60 \%)$ - consists of diallyl disulphide which has the odour of garlic. It is rendered colourless by distilling with a little potassium.

3. Fraction III (20\%) - Boiled between $112-122 \mathrm{c}$ at $16 \mathrm{~mm}$ pressure.

4. Fraction IV (10.5\%) - Boiled above 122-1t $16 \mathrm{~mm}$ pressure and decomposes on further distillation. It consists mainly of poly sulphides.

5. Seeds yeild aromatic oil. The juice, more particularly its oil constituents

6. are rich in organically bound sulphur (organic sulphides). Iodine and salicic acid combination apart from important nutrient and complementary substances containing vitamins. ( $\operatorname{Dr}$ K.M. Nadkarni - Indian Materia medica vol I, p 65).

7. Co vallito and co worker (1944) isolated allicin the antibacterial principle from ground garlic cloves. It has the formula $\mathrm{C}_{6} \mathrm{H}_{10} \mathrm{OS}_{2} \mathrm{~mol} \mathrm{Wt} 162$. It is irritating to the skin and the odour is more characteristically that of garlic than is that of various allyl sulphides. It is relatively stable in $0.2 \%$ aqueous solution and is very unstable in pure state. It is stable at $0.3-0.4 \%$ for long period.

8. Siddique and co workers while investigating sulphur containing antibiotic principle of plant origin. Reinvestigating garlic and observed that, by dialyzing the whole clove with ether for a period of 6 hours, highly active concentrate was obtained in a yield of $0.4 \%$ fractionisation of the active principle by a process of partitioning between Non miscible solvents showed that there are 2 active substances present in Garlic. One of which is active against staphylococcus and E coli. Whereas second shows actively towards staphylococcus allisatin I and Allisatin II.

9. Apart from the above active constituents a crystalline substances $\mathrm{m} \mathrm{p} 79-80^{\circ} \mathrm{c}$ has also been isolated from the alcohol insoluble fraction of the residue. - Chopra Indegenous drugs of India II, 1982 part III.

Garlic is much used in India cookery as a condiment or spice it contains: Contents of Garlic

\begin{tabular}{|c|c|}
\hline Moisture & $62.8 \%$ \\
\hline Protein & $6.3 \mathrm{mg}$ \\
\hline
\end{tabular}




\begin{tabular}{|c|c|}
\hline Fat & $0.1 \mathrm{mg}$ \\
\hline Carbohydrate & $29.0 \mathrm{mg}$ \\
\hline Calcium & $0.03 \mathrm{mg}$ \\
\hline Phosphorous & $0.311 \mathrm{mg}$ \\
\hline Iron & $1.3 \mathrm{mg}$ \\
\hline Thiamine & $0.06 \mathrm{mg}$ \\
\hline Riboflavine & 0.23 \\
\hline Mucin & $0.4 \mathrm{mg}$ \\
\hline Folic acid & 6.15 \\
\hline Iodine & $0.07 \mathrm{mg} / 100 \mathrm{~g}$ \\
\hline Calori value & $145 \mathrm{cal} / 100 \mathrm{~g}$ \\
\hline Vit C & $13 \mathrm{mg} / 100 \mathrm{~g}$ \\
\hline
\end{tabular}

- It is reported to contain Copper. (Nutritive value of Indian foods, Indian journal of medical Research 1972, 60.)

- The bulbs on distillation yields $0.06-0.1 \%$ of an essential oil, containing allylpropyl disulphide, $\mathrm{C} 6 \mathrm{H} 12$ S2(6\%), diallyl disulphide C6H10S2 (6\%) and two or more sulphur containing compounds. The oil is rarely used medically, although it has been recommended for internal use, as a tonic and stimulant to the stomach and as a vermifuge. Its chief use is to spice the foods. (The Wealth of India Vol I 1948 p 565)

- Allyl alcohol, sulphur compounds such as Allicin (diallyl thiosulphinate), alliin [(+)-S-allyl-LCysteinesulphoxide], diallyl sulphide, diallyl disulphide and allyl propyl sulphide are the major constituents from the essential oil. (Quality standards of Indian medicinal plants vol 3/38).

\section{Contents of dry powder of Garlic}

\begin{tabular}{|c|c|}
\hline Chemical substance & Percentage (\%) \\
\hline Water & 5.2 \\
\hline Nitrogen & 17.5 \\
\hline Fat & 0.6 \\
\hline Mineral & 3.2 \\
\hline Fibers & 1.9 \\
\hline Sugars and carbohydrate & 17.4 \\
\hline Calcium & 0.1 \\
\hline Iron & 0.42 \\
\hline Sodium & 0.04 \\
\hline Potassium & 1.1 \\
\hline Vit A & $175 \mathrm{IU} / 100 \mathrm{~g}$ \\
\hline Vit B & 0.68 \\
\hline VitB2 & 0.08 \\
\hline Niacin & $12.0 \mathrm{mg} / 100 \mathrm{gm}$ \\
\hline Calories & $380 \mathrm{cal} / 100 \mathrm{gms}$ \\
\hline
\end{tabular}

1. Y-gluatamyl peptides isolted from garlic are almost identical with those present in onion. They include $y$ glutanyl phenyl alamine, y-glutamyl-S- methyl cystine, 1-y-glutanyl-Sb-carboxy-b-methyl-ethyl ystrynyl-glymi, S- allyl 1-cystine and y-1 glutanyl-5-allyl-1-cystine and y-1-glutanyl-5-propyl cysteine were present in garlic only. (Chemical abstract 1962).

2. The amino acids present in the bulbs are leucine, methomine, S-propyl-1- Cysteine (-)-S-propenyl-1Cysteine, S-methyl-cysteine-S-allyl-systeminesulphodioxide(allin),S-ethyl-1-cysteine sulphodioxide.

\section{Controversial Aspect Of Lashuna:-}

Some authors consider Grunjanaka as Rasona. Grunjanaka is the most controversial plant. The commentator have described it as

1. Lohitha palandu - Red onion

2. Rasonaka - Garlic or a species of Garlic.

Dhanwantari and Raja nighantu have also described it as Maharasona and Mahakanda. So it is a species of Garlic. Bapalalchandra has described it as Grunjana is exactly like onion, in smell, form and taste. The only difference is that this has smaller stem and leaves than onion. Chakrapani has identified Lashuna as follows:

1. Grunjanakaha swalpanaalpatra palandureva - Su 27/179 
2. Lohitapalandu - Chi $17 / 128$

3. Rasonaka kimva Grunjanaka shobhanjanam - Ch 12/60

Bapalal confirms it as:

1. Grunjanaka is a small piece of onion with little stem and leaves

2. Red onion, it is garjara

3. A variety of Garlic or

4. It may be shigru - Moringa pterygosperma.

One big variety of garlic is known as ekakalee lasan, and it is allium Ascalanicum Linn Liliaceae. Onion is allium cepa Linn. So both belong to the same family.

Cultivation And Propagation:

1. Garlic grows almost in all conditions as the onions, except that it favours a richer soil and a higher elevation (3000-4000). A well drained moderately clayed loam is best suited for its cultivation. It requires a cool moist period during growth and relatively dry period during the maturing of the crop. It

2. takes longer (4-5 months) than onion to mature, and is consequently grown as a late season irrigated crop. In south India it is rotated with ragi, chillies, Maize, potatoes and beans. (Yegna Narayan Aiyer).

3. The cloves or separated bulbs are planted during Sep-Oct in the plains and Feb- March in the hills. About 250-300 IB of bulbs are required to plant acre.The bulbs begin to form in about 2 months.

Part Used:- Bulb.

Posology:

1. Powder- 3 to 4 gms (API vol 3 )

2. The average daily dose is $4 \mathrm{gms}$ of garlic or $8 \mathrm{gms}$ of essential oil (PDR for Herbal medicine Ist edition, P 626-628)

3. 3-4 gms is the general dose (Database of Indian medicinal plants vol 6/56)

4. Kanda kalka - 3 to 6 gms

5. Taila -1 to 2 drops

6. Rasona panda -2 tola

7. Swarasa -10 to 30 drops

8. Kalka -2 to 3 masha

9. Ksheerapaka - 1 to 2 tola ( Indian medicinal plants vol 2, Km Nadkarni

\section{Rasa Panchaka}

Table.9: Rasa panchaka of Lashuna

\begin{tabular}{|l|l|}
\hline Rasa & Amlarahita pancha rasa ( Madhura, Lavana, Katu, Tikta, Kashaya) \\
\hline Pradhana rasa & Katu \\
\hline Guna & Snigda, Teekshna, Picchila, Guru, Sara \\
\hline Veerya & Ushna \\
\hline Vipaka & Katu. According to kashyapa - Madhura \\
\hline
\end{tabular}

According to Avayava (Bhava Prakasha)

$\begin{array}{lll}\text { 1. } & \text { Moola } & \text { - Katu } \\ \text { 2. } & \text { Patra } & \text { - Tikta } \\ \text { 3. } & \text { Naala } & \text {-Kashaya } \\ \text { 4. } & \text { Naalagra } & \text {-Lavana } \\ \text { 5. } & \text { Beeja } & \text {-Madhura }\end{array}$

According to Kashyapa Samhitha

1. Beeja - Katu

2. Pushpanaala - Lavana, Tiktha

3. Patra - Kashaya

Doshagnatha - Kapha vata shamaka

1. By its Katu and Teekshna Guna it is Kapha shamaka.

2. By its Snigdha, picchila, guru and ushna guna it is Vatashamaka.

3. Due to its ushna guna it increases Raktha and Pitta. 


\title{
Guna karma according to Raja Nighantu:
}

Katu, Picchila,Snigdha,Guru, Madhura Rasayuktha, Adhika balaprada,Veeryavardhaka, Medhya, Netrahitakara, Bhagna sandhana, Adhika teekshna. He mentions it as GRUNJAN

Kanda- Madhura and katu rasa

Raktha Rasona - Used in Hrudaya roga, Jeerna Jwara, Udarashoola, Malavardhana, Gulma, Aruchi, Mutrakruchhra, Arshas, Kusta, Shotha, Vatavikara, Krimiroga.

\section{KARMA:-}

Balya, Asthisandhana,Vajeekarana, Agnideepana, Hrudya, Paachana, Dhatuvardhana, Krimighna, Kantya, Rasayana, Vrushya, Balavarnakara, Medha Hita, Netrya, Swedajana, Mootrala,Uttejaka,

kaphanissaraka, Durgandhahara,Rakthotklesha, Shotha, Vedanasthapana, Medhya, Netrya, deepana, Anulomana, Shoolaprashamana, Yakruthuttejaka, Kothaprashamana.

\section{Karma According to Kashyapa}

It acts as Amrutha and Rasayana. By Lasuna sevana, Danta, Mamsa, Nakha, Smashru, Kesha, Varna, Avastha and Bala never under go ksheena. Stana shithilatha won't occur in women by consuming Lasuna and attain Roopa, Santana, Bala and Aayu. Soubhagya vruddi and Youvvana gets druda. By consuming Lashuna, Stree attain Shuddi and rogas occurring due to Graamya Dharma are prevented. She will be devoid of rogas afflicting kati, Shroni and Anya angas and even never suffer from Vandhya and Apriya darshana. Purusha becomes Druda, Medhavi, Deergayu, Sundara, Santhanayuktha, Shukradharana and Vruddhi takes place.By Lashuna sevana, patients attain Vrushya, Shareera mrudutha and Kanta madhuratha takes place, Grahani doshas are cured. (K.S Lashuna kalpa 18-25).

\section{Pharmacological Action:}

Antibacterial, Uterine stimulant, Antifungal, Anti-inflammatory, Hypoglycemic, Anti-arthritic, Hypolipaedemic, Anti-coagulant, Hypoprotienemic, Hypochloestermic, Anti-hypertensive, Fibrinolytic, Anti-diabetic, Anticancer, Anti-reckettisal, Anti-tumour, Anti- tubercular, Anti-oxidant, Anti-ageing, Cardioprotective, Cardiovascular depressant, Larvicidal.

\section{Chemistry Of Garlic}

Garlic contains at least 33 sulfur compounds, several enzymes, 17 amino acids, and minerals such as selenium. It contains a higher concentration of sulfur compounds than any other Allium species. The sulfur compounds are responsible both for garlic's pungent odor and many of its medicinal effects. Dried, powdered garlic contains approximately $1 \%$ alliin (S-allyl cysteine sulfoxide). One of the most biologically active compounds, allicin (diallyl thiosulfinate or diallyl disulfide) does not exist in garlic until it is crushed or cut; injury to the garlic bulb activates the enzyme allinase, which metabolizes alliin to allicin. Allicin is further metabolized to vinyldithiines. This breakdown occurs within hours at room temperature and within minutes during cooking. Allicin, which was first chemically isolated in the 1940's, has antimicrobial effects against many viruses, bacteria, fungi and parasites. Garlic oil, aged garlic and steam-distilled garlic do not contain significant amounts of aliin or allicin, but instead contain various products of allicin transformation; none appears to have as much physiologic activity as fresh garlic or garlic powder

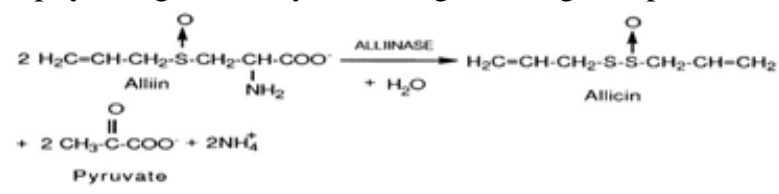

\section{Pharmacokinetics:-}

Alliin an active constituent of garlic is well absorbed orally, reaching maximum serum concentration within 10 minutes and urinary measurement suggest a minimum absorption rate of $65 \%$ for alliicin and $73 \%$ for vinyldithiins. Studies on isolated rat linear found that alliicin administered at $400 \mathrm{mcg} / \mathrm{min}$ was $95 \%$ metabolized on first passinto diallyl sulfide, allyl mercapton and other break down products.Oral S-allyl cysteine gets absorbed in rats, mice and dogs. Essential oil administered per rectum in human adults at dose of $180 \mathrm{mg} /$ person together with milfoil, amylocaine and chlorophyll got absorbed through the rectal mucosa.

\author{
Amayika Prayoga: \\ Amayika prayoga of Lashuna \\ \begin{tabular}{|l|l}
\hline Rasavahasrotas & Hrudroga, Jeernajwara, Vishamajwara, Dourbalya, Shosha.
\end{tabular} \\ \begin{tabular}{|l|l|}
\hline Rakthavahasrotas & Kushta, Dadhru, Charmaroga.
\end{tabular}
}


Critical Analysis of Lasuna (Role of Lasuna in Different Branches of Ayurveda)

\begin{tabular}{|l|l|}
\hline Mamsavahasrotas & Kotha, Vrana. \\
\hline Medavahasrotas & Urustamba. \\
\hline Asthivahasrotas & Sandhigatavata, Grudrasi, Asthibhagna. \\
\hline Shukravahasrotas & Shukraduorbalya. \\
\hline Annavahasrotas & Ajeerna, Agnimandya, Arshas, Shoola, Gulma, Vibhanda. \\
\hline Pranavahasrotas & Shwasa, Yakshma, Swarabheda. \\
\hline Mootravahasrotas & Mootrakrucchra. \\
\hline Arthavahasrotas & Yonivyapath, Kashtarthava. \\
\hline Manovahasrotas & Apasmara, Mastishkadourbalya. \\
\hline
\end{tabular}

Showing The Properties And Action Of Lashuna:

\begin{tabular}{|l|l|l|l|l|l|l|l|l|l|l|l|l|l|l|}
\hline \multicolumn{1}{|c|}{ RASA } & BP & CS & DN & KDN & KS & MN & NP & SN & SS & AS & RN & HS & NR \\
\hline Madhura & + & & + & + & + & + & & & & & + & + & + \\
\hline Lavana & & & & & + & & & & & & & + & + & + \\
\hline Katu & + & + & + & + & + & + & + & + & + & + & + & + & + \\
\hline Tiktha & + & & & & + & & & & & & & + \\
\hline Kashaya & + & & & & & + & & & & & & & & + \\
\hline
\end{tabular}

\begin{tabular}{|l|l|l|l|l|l|l|l|l|l|l|l|l|l|l|}
\hline GUNA & BP & CS & DN & KDN & KS & MN & NP & SN & SS & AS & RN & HS & NR \\
\hline Guru & + & + & + & + & & + & + & + & + & + & + & + & + & + \\
\hline Snigdha & + & + & + & + & + & + & & & & & + & + & + & + \\
\hline Teekshna & + & & & + & + & & & & & + & + & & + & + \\
\hline Ushna & + & + & + & + & + & & + & + & + & & & & \\
\hline Sara & + & & & + & & & & + & + & + & + & & & \\
\hline
\end{tabular}

\begin{tabular}{|c|c|c|c|c|c|c|c|c|c|c|c|c|c|}
\hline \multicolumn{14}{|c|}{ Virya } \\
\hline EERYA & BP & CS & DN & KDN & KS & MN & $\mathbf{N P}$ & SN & SS & AS & RN & HS & NR \\
\hline Ushna & + & + & + & + & + & + & + & + & + & + & + & + & + \\
\hline
\end{tabular}

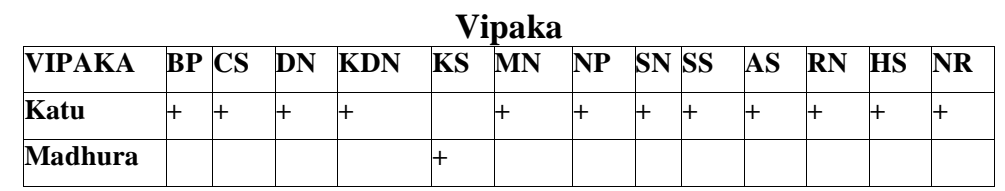

\section{Karma}

\begin{tabular}{|l|l|l|l|l|l|l|l|l|l|l|l|l|l|l|l|}
\hline KARMA & BP & CS & DN & KDN & KS & MN & NP & SN & SS & AS & RN & HS & NR \\
\hline Balya & + & + & + & + & + & + & + & + & + & + & + & + & + \\
\hline Asthi Sandhana & + & + & + & + & + & + & + & + & + & + & + & + & + \\
\hline Vajeekarana & + & & & & & & & & & & & & & + \\
\hline Agnideepana & + & + & + & + & + & + & + & + & + & + & & & \\
\hline Hrudya & + & & & & & & & & & & & & & & \\
\hline Pachana & & & & & & & + & & & & + & & & \\
\hline Dhatuvardhana & & & & + & & + & & & & & & & \\
\hline Krimighna & & & & & + & + & & & & & & & \\
\hline Kantya & + & + & + & + & & & & + & & & + & + & \\
\hline Rasayana & + & & + & & & + & & + & & & & + & + \\
\hline
\end{tabular}

Indications of Lasuna

\begin{tabular}{|l|l|l|l|l|l|l|l|l|l|l|l|l|l|}
\hline INDICATION & BP & CS & DN & KDN & KS & MN & NP & SN & SS & AS & RN & HS & NR \\
\hline Vatavyadhi & + & + & & + & + & & & & & + & + & + & + \\
\hline Kshaya & & & & & + & + & & & & & & & \\
\hline
\end{tabular}




\begin{tabular}{|c|c|c|c|c|c|c|c|c|c|c|c|c|c|c|}
\hline Sandhivata & + & & & & & + & + & & & & & & & \\
\hline Ajeerna & + & & & & + & + & & & & & & & & + \\
\hline Udarashoola & + & & & + & & & + & & & & + & + & + & \\
\hline Kasa & + & & & & & & & & & & & + & + & + \\
\hline Asthibhagna & + & & + & & + & & & & & & & & & \\
\hline Shwitra & & & + & + & + & & & + & + & + & & & & + \\
\hline Rasayna & + & & & + & & + & + & & & + & + & & & \\
\hline Krimiroga & & + & + & + & + & & & & & + & + & + & & + \\
\hline Kusta & + & + & + & + & + & & & & & + & + & + & & + \\
\hline Jeernajwara & + & & & & + & & + & & & & + & + & + & \\
\hline Shukrakshaya & + & + & & + & + & & & & + & + & & & & \\
\hline Shotha & & & & + & + & & & & & & & & & \\
\hline Gulma & & & & & + & & & & & & + & & & + \\
\hline Amavata & & & & & + & + & & & & & & & & \\
\hline Hrudroga & + & & & + & & & & & & & + & + & $t$ & \\
\hline
\end{tabular}

\section{Contra Indications Of Lashuna:}

1. Atiambupana, suffering from ama, kshuda, matsya, yana, adyavata, atapasevana, athibhaksya , chinta, diwaswapna, jagarana, ativyayama, pandu, udararoga, kshatajashopha, trishna, atipana, chardi, vishvrana, pittavikara, akshivikara, atiksara, ksheena shareera.( A H U 39/128)

2. Prameha, aruchi, garbhini, rakthapitta, moorcha, visarpa, shosharogi, vamana peeditha, balaka, bhramapeeditha, madatura, kusta, rakthavata.( H S kalpa 127)

3. The person who is consuming loha, should avoid Rasona. ( B R 2/155)

4. It is contraindicated in

5. Grahani (B R 8/617)

6. Pandu (B R 12/147)

7. Rakthapitta (C S Ni 2/4)

8. Visarpa (C S Chi 21/19)

Because all these disorders pitta is the predominate dosha. Consumption of lasuna causes aggravation of above mentioned disorders.

- Acc to Kashyapa, Lashuna is contraindicated in kapha and pittaroga, shareerahrasa, vruddavastha, agnimandya, soothika, garbhini, shishu, amaroga, jwara, atisara, kamala, arshas, urusthambha, vibhandha, gala, mukharoga, sadyavantha, vikrutha shirovirechana, shosha, trushna, chardi, hikka, shwasa, daridra, duratma, sadyaniruha, anuvasitha. (K S kalpa 21/34).

\section{Safety And Toxicity:}

1. Garlic is commonly used as food as well as medicine. $2000 \mathrm{mg} / \mathrm{kg}$ dose did not reveal any toxic effects when given for rats for 6 months. The main side effects is its unpleasant breath odor, other side effects are rare. Garlic if taken in higher doses may cause heartburn, nausea, vomiting, diarrhea, tachycardia, insomnia and facial flushing. Topical application of garlic can cause skin irritation, blistering and even burns.

2. Garlic has certain adverse effects like flatulence, esophageal and abdominal pains, small intestinal obstruction, contact dermatitis, rhinitis, asthma, bleeding, myocardial infarction, urticaria, angioedema, anaphylaxis, skin blisters and ulceronecrotic lesion.

3. Acute toxicity of garlic is rare in human but in farm animals may be seen, consuming acid garlic includes haemolytic anemia, jaundice, haemoglonuria, kidney and liver damage.

\section{Samsthanika prayoga}

Bahya -

1. Sandhivata, Grudrasi, Arditha, Pakshaghata, Urusthambha. In Shotha and Vedana pradhana vikaras as lepa.

2. In Parshwa Shoola, kalka lepa and swarasa mardana.

3. In Visha prani damsha as lepa.

4. In Karnashoola, lashuna rasa pakva taila is used. 


\section{Abhyanthara prayoga}

1. Nadi samsthana- Due to its vatagna property it is used in Pakshagata, Grudhrasi, Sandhivata, Vataroga \& Masthishka dourbalya.

2. Pachana samsthana- It is used in agnimandya, aruchi, ajeerna, vibhandha, shoola, gulma, krimi and arshas.

3. Rakthavaha srotas- By its uttejaka guna it is useful in Hruth roga and Hruth janya shotha.

4. Pranavaha srotas- It is useful in jeernakasa, shwasa, yakshma and swarabheda. By its volatile principle it kills kshayaja krimi, does sandhana of phuphusa tantu.

5. Mootravaha srotas - It is useful in vatika mootrakrucchra.

6. Shukravaha srotas- By its Shukrajanana property it is useful in shukra dourbalya. By its Artavajanana property it is useful in Kastarthava.

7. Satmeekarana- Due to its Rasayana property it is useful in Samanya dourbalya and by its Sandhaneeya guna it is used in Asthibhagna.

8. Twacha- It is useful in Kusta, Kotha.

9. Taapakshama- By its Jwaragna property it is useful in Jeernajwara, Typhoid, and Diptheria

\section{Pharmacology}

\begin{tabular}{|l|l|}
\hline Activity & Part \\
\hline Anti-hypertensive activity & Aqueous extract \\
\hline Cholesterol lowering effect & Alcoholic extract \\
\hline Anti-thrombotic activity & Powder \\
\hline Anti-oxidant activity & Old garlic powder \\
\hline Hypoglycemic activity & Powder \\
\hline Anti-tuberculosis effect & Bulbs \\
\hline Anti-atherosclerotic & Powder \\
\hline
\end{tabular}

Research Profile

\begin{tabular}{|l|l|l|}
\hline Activity & Part used & Researcher \\
\hline Anti-inflammatory activity & Bulb & Sreenivas murthy et al 1962 \\
\hline Anti-inflammatory activity & Alcoholic extract & Bakun et al 1969 \\
\hline Anti-diabetic activity & Swarasa & Jain et al 1969 \\
\hline Anti-hypertensive activity & Whole plant (Kalka) & Devt apoth Zlg 1966 \\
\hline Hypocholestreamic activity & Juice and Essential oil & Bordia et al 1974 \\
\hline Coagulation activity & Alcoholic extract & Gurdeep sing and Chaturvedi \\
\hline Hypocholestreamic activity & Aqueous extract & Augusti 1977 \\
\hline
\end{tabular}

\section{Monogram of Lasuna}

\section{Single bulb Lasuna}

\section{Macroscopic:}

A tunicated globular single bulb without any bulblets, measuring about $2.5 \times 5 \mathrm{~cm}$ in diameter, gradually tapering towards the apex, bearing sterile sheathing leaves, placed on a woody disc like stem, attached with 20-40 stout fibrous root at the base, shape oval to rounded, outer skin whitish Odor strong characteristic, alliaceous, taste persistently pungent and acrid. Fig A.

\section{Microscopic:}

Transversely cut surface from the center of the clove is somewhat oblong with a wide parenchymetous, ground tissues and scattered vascular strands, the central portion being occupied by circles of 2 to 3 fleshy leaves, the innermost two being horse shoe shaped and placed in opposite directions.Fig.1-3

Each foliaceous leaf of the clove is composed of mesophyll tissues, enclosed by outer and inner epidermis except the outer most one, which is devoid of the inner epidermis. It is composed of tubular tangentially elongated cells covered with thick cuticle and a wide 10 to 12 layered parenchymatous ground tissues, scattered with vascular bundles. The epidermis of the remaining leaves are composed of highly thick walled radially elongated cells and a layer of hypodermis underneath the upper epidermis, the vascular bundles are encircled by a parenchymatous sheath Fig. 4-5.

\section{Powder microscopy: Organoleptic characters:}

Colour, taste, odour, and powder nature of single bulb Lasuna recorded by sensory characters and Yellowish cream colored, shows fragments of parenchymatous cells of mesophyll with yellowish contents, group of spiral and annular vessels of vascular strands associated with parenchyma, filled yellowish contents, oil 
globules, elongated thin walled parenchymatous cells of the epidermis and some olioresine content, overlapping with hexagonal hypodermal cells containing prismatic crystals of calcium oxalate and elongated thick walled, lignified fibres. Fig.11-16.

\section{Histochemical test:}

Hard sections of the bulbs treated with various reagents to detect the presence and absence of tannin, starch, calcium oxalate etc.

\section{Multi bulb Lasuna: \\ Macroscopic:}

A tunicated globular bulb 3.5 to $6.5 \mathrm{~cm}$ in diameter, gradually tapering towards the apex, bearing sterile sheathing leaves, placed on a woody disc like stem,attached with 20-40 stout fibrous root at the base,enclosing 10-25fleshy bulblets called 'clove' arranged in whorled fashion around the center, plano-convex with 2 or 3 ventral flat surfaces separated by longitudinal ridges meeting at the base, forming anirregular margin around the 5-10 mm wide depression. Odor strong characteristic, alliaceous, taste persistently pungent and acrid. Fig B.

\section{Microscopic:}

Transversely cut surface from the center of the clove is somewhat oblong with a wide parenchymatous, ground tissues and scattered vascular strands, the central portion being occupied by circles of 5 to 6 fleshy leaves, the innermost two being horse shoe shaped and placed in opposite directions. Fig. 6-7.

Each foliaceous leaf of the clove is composed of mesophyll tissues, enclosed by outer and inner epidermis except the outer most one, which is devoid of the inner epidermis. It is composed of tubular tangentially elongated cells covered with thick cuticle and a wide 10 to 12 layered parenchymatous ground tissues, scattered with vascular bundles. The epidermis of the remaining leaves are composed of highly thick walled radially elongated cells and a layer of hypodermis underneath the upper epidermis, the vascular bundles are encircled by a parenchymatous sheath Fig. 8-10.

\section{Powder microscopy: Organoleptic characters:}

Colour, taste, odour, and powder nature of single bulb Lasuna recorded by sensory characters and results were depicted in table No. 1. Yellowish cream colored, shows fragments of parenchymatous cells of mesophyll with yellowish contents, group of spiral vessels of vascular strands associated with parenchyma, filled yellowish contents, elongated thin walled parenchymatous cells of the epidermis, overlapping with hexagonal hypodermal cells containing rod shaped prismatic crystals of calcium oxalate and elongated thick walled, some of the scleroids and also pitted parenchyma cells are also observed. Lignified pitted epidermal cells underlying with hexagonal hypodermal cells indicates the admixture of fragments of dried outer and inner scales.Fig.17-22.

\section{Histochemical test:}

Hard sections of the bulbs treated with various reagents to detect the presence and absence of tannin, starch, calcium oxalate etc.

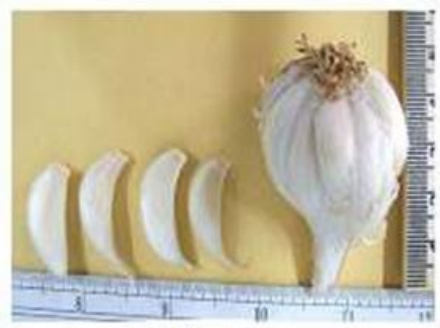

Fig. A

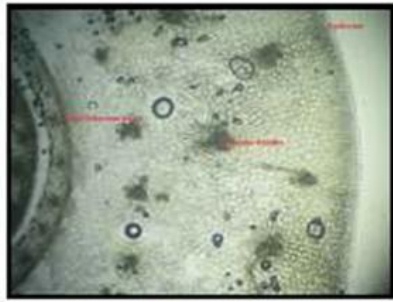

Fig: 1

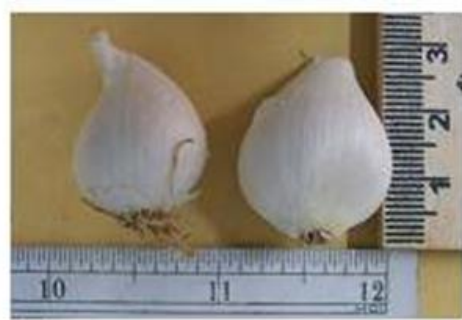

Fig. B

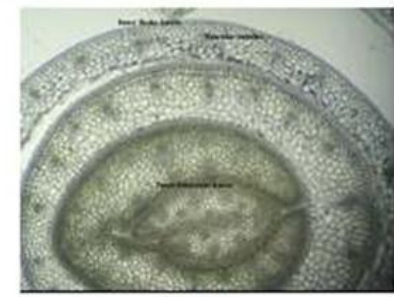

Fig: 2 


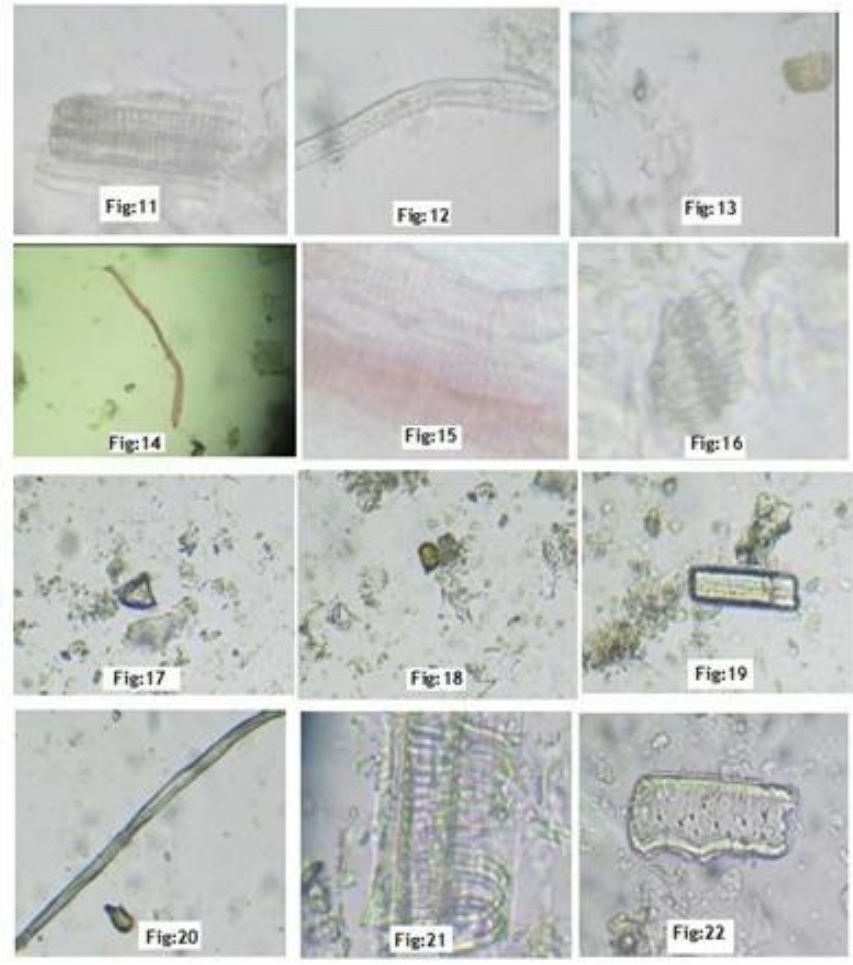

\section{Powder microphotographs:}
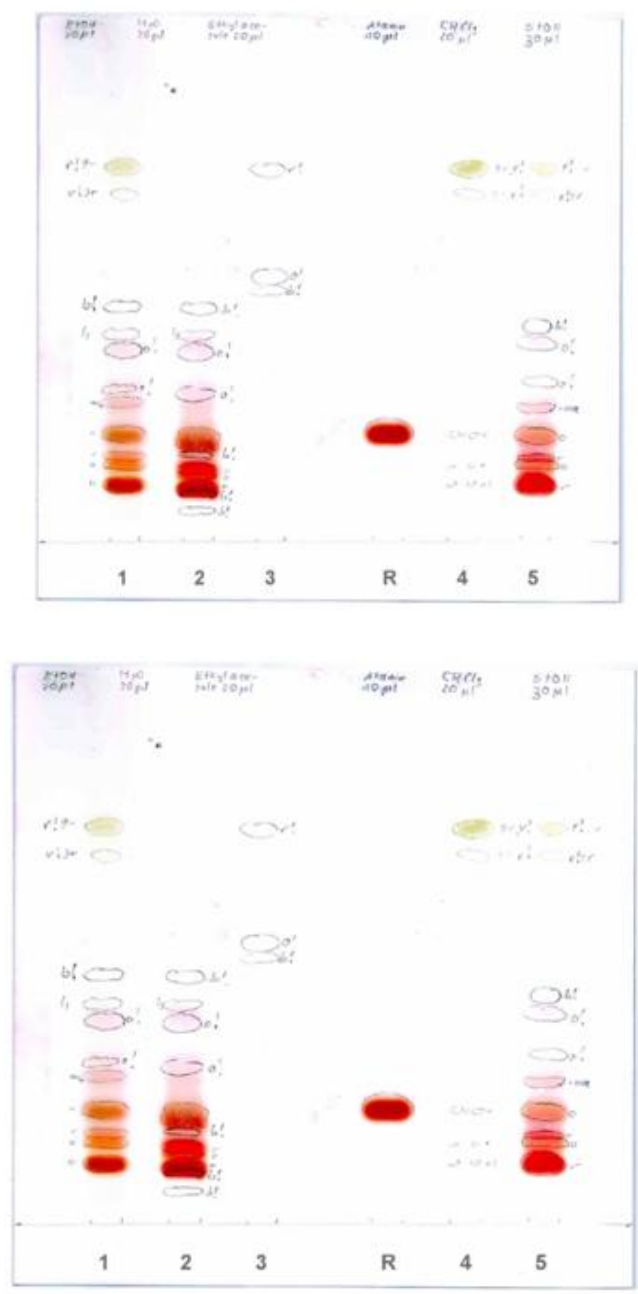


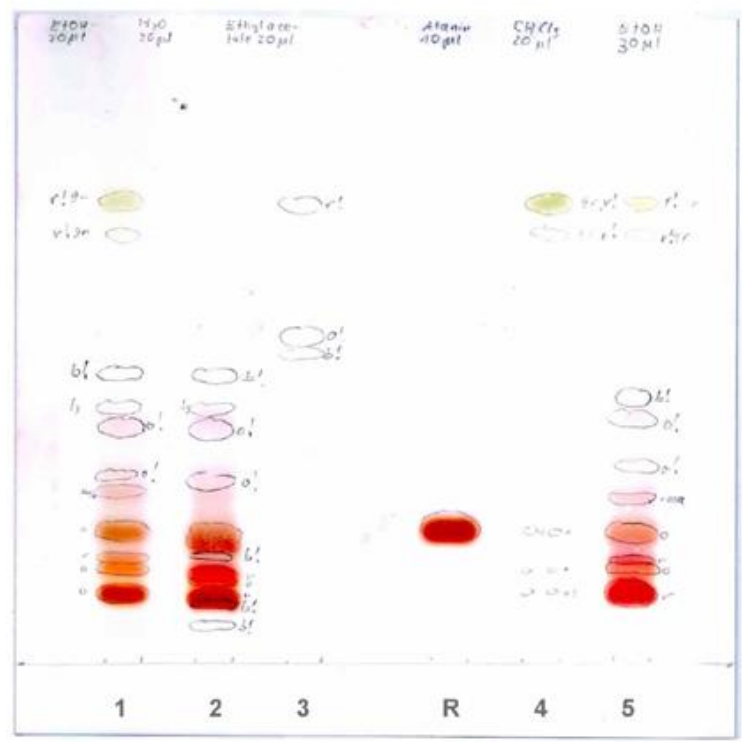

\section{TLC of alliins / allicins}

TLC was performed according to (Kanaki and Rajani 2005 [73]. For analysis of the alliins and allicins n-butanol: acetic acid: water 60:40:20 was chosen as solvent system. The amino acid Alanin was used as reference showing similar Rf according to alliin. Therefore $5 \mathrm{mg}$ of alanin were dissolved in $1.5 \mathrm{ml}$ methanol. Detection was made by spraying with ninhydrine reagent. Spray reagent for detection of amino (-NH2) groups: $200 \mathrm{mg}$ of ninhydrine was dissolved in $100 \mathrm{ml}$ water. After heating at $100^{\circ} \mathrm{C}$ for $5 \mathrm{~min}$ alanin and the alliins could be detected as red or pink spots, while allicins were visualized as orange spots in VIS.

TLC on alliins and allicins in the wild garlic extracts fractions,

developed in the solvent system butanol: acetic acid: water 60:40:20, sprayed with ninhydrine solvent. 1 $=$ ethanolic extract $(20 \mu \mathrm{l}), 2=$ aqueous phase $(20 \mu \mathrm{l}), 3=$ ethyl acetate extract $(20 \mu \mathrm{l}), 4=$ chloroformic extract $(20 \mu \mathrm{l}), 5=$ ethanolic extract $(30 \mu \mathrm{l}), \mathrm{R}=$ alanin (marker).

\section{Anti-hypertensive activity}

\section{Role Of Lasuna In Kayachikitsa}

Numerous studies have focused that garlic has the potential to modestly lower the blood pressure. The Anti-hypertensive effect of garlic can be explained with different types of mechanisms. Aqueous extract of garlic allicin and ajoene have a vasodilatory and hyper polarizing effects. Allicin and ajoene together have strong dilatory effect that the total extracts finally exert the hyper polarizing effect on the vascular smooth muscles of all membranes. The vasodilatory influence of garlic can be outlined by the following reaction loop. Garlic extract opens additional $\mathrm{K}+$ channels and thus lead to membrane hyper polarization.this means that substance in the extract that is (allicin and ajoene).have $\mathrm{K}+$ channel opening property (phytopharmacological $\mathrm{K}+$ channel openers ) voltage dependent calcium channels are closed by this hyper polarization, the calcium invert current into the vascular muscles cell decreasing and also the intracellular calcium concentrated. The result is vasodilation which helps in lowering hypertension.

The other mechanism of action of garlic on hypertension is nitric oxide metabolism. In harmotensive humans, the endothelium modulates fans. Mainly by the prediction of nitric oxide. Defective basal release of nitric oxides seems secondary to blood pressure increasing while impaired evoked endothelium dependent vasodilation is probably a primary phenomenon. This latter endothelial dysfunction seems to be caused by the simultaneous presence of the alteration in the $\mathrm{h}$-arginnise-nitric oxide pathway and the production of carstrictor prostanoide. Defective nitric oxide production is already detectable in normotensive offspring of hypertensive points and young essential hypertensive. Nitric oxide produced from arginine by nitric oxide syntheses (NOS) which can exist in both constitutive and inducible isoforms. The main action of nitric oxide is lowering of blood pressure. Garlic is known to increase nitric oxide synthase activity in both cell and cell free system. The activity of calcium nitric oxide synthase in increasing several folds upon addition of garlic extract. Although arginine is present in garlic, the activation of calcium nitric oxide synthase is independent. The activation is partially abolished when garlic is heated.

In pregnancy R1 (resistance index) and pulsatility index (PI) of the uterine arteries normally decreases this reflux increases blood flow and pregnancy progresses. Administration of garlic tablets delaying the first trimester of the pregnancy appears to decrease both R1 and PI. Placental tissue nitric oxide synthase 
activities and polyamine cartraction do not appear to be affected by administration of Garlic.Garlic may also help to alleviate complex patho physiological conditions such as eclampsia and growth retardation. Some of the study suggests that nitric oxide donors may arrest the initiation of preterm labor and garlic maysimilarly prove useful in women at risk from this condition.

\section{Cholesterol lowering effect}

Garlic preparations have shown to exert hypo cholesterolermic effects in animals and man. Recent research invitro has revealed multiple interactions of garlic compounds with the biosynthetic pathway for cholesterol in rat lives resulting in moderate but significant inhibition using rat's hepatocytes. In primary culture it can be demonstrated that the incorporation of carbon-14 labeled acetate into non saponifiable lipids is influenced mainly on two levels. At the level of HMGCO-reductares At the steps of biosynthetic pathway, particularly at the lanosteral 14 demethylare. Lasuna can be compare with Atervostatin and it releases the hydrogen sulfide in obese and hyperlipidemic patients.

Overall inhibition caused by garlic extract at $0.5 \mathrm{mg} / \mathrm{ml}$ ranged within $20-30 \%$ in a period of two homes with regards to the first influence it was noted that low concentration garlic compounds do not exert direct inhibition of HMGCO a reductase, but the activity is inhibited via indirect mechanism involving different signal transduction pathway. The most important interaction seems to be the amplification of the AMP dependant kinace mediated phosporylation of HMGCO-a reductare by garlic derived organo sulphur compounds particularly di-allyl-di-sulphide. This influence is detectable down to di-allyl-di-sulphide and is apperent with changes of intracellular AMP as well as the palmitotyl-CO-A induced stimulation of the respective kinase. The sensitive mechanism not only affects Hepatic cholesterol biosynthesis but also fatty acid biosynthesis via acetyl CoA in a concerted action. It is conceivable that a similar AMP dependent kinase activity on memory and adipose tissue. Another mechanism of comparatable sensitivity was amplification of adenosine induced inhibition by allicin at the level of adenosine receptor this influence seemed to be mediated via adenosine induced changes in intracellular $\mathrm{Ca} 2+$ rather than C-AMP. The advantage of garlic derived organosulphur compounds as inhibiter of cholesterol biosynthesis can be summarized as follows. They enhance in a sensitive manner the physiological mechanism that reduces endogenous cholesterol biosynthesis resulting in a high biocompatibility of their effects. They exert multiple different actions leading to a balanced response of the cells and the whole organs. Presumably, due to their mode of action they do not affect cholesterol biosynthesis in organs that need these molecules for production of hormones and other functions. They do not seem to produce adverse effects during long term applications of garlic preparations. This indicates that garlic compounds mainly allicin, ajoene and diallyl di sulfide exert multiple effects on hepatic cholesterol biosynthesis.

\section{Anti-thrombotic activity}

$900 \mathrm{mg}$ of standard garlic powder daily significantly decrease spontaneous platelets aggregation. Garlic has been found in human trails to increase fibrinolytic activity either when taken in the single dose or after prolonged consumption. The antithrombotic activity prevents rise in fibrinogen level and prolongs bleeding.

\section{Anti-oxidant effect}

Antioxidant property has been found in old garlic. In a study the effects of various concentration and incubation time intervals of di allyl disulfide, an active principle of garlic on cell viability and glutathione concentration and its treated enzyme activity in rat hepatocyte were investigated. Intracellular GSh contain of cell treated with 0.5 and $1 \mathrm{ml}$ diallyl disulfide was higher than in controls. This phenomenon is beneficial to the detoxification and antioxidation capabilities of hepatocytes.

\section{Anti-atherosclerosis activity}

Garlic powder at a dose of $900 \mathrm{mg} /$ day significantly showed reduction in the development of atherosclerosis as measured by ultrasound. Even in individual with same blood pressure and cholesterol levels, those who took garlic showed less evidence of damage to their arteries. Anti- atherosclerosis, benefits of oral garlic are due to effects other than reduction in cholesterol and blood pressure. Recent study of 200 individuals suggests that garlic causes hardening of the arteries not only by lowering cholesterol or blood pressure but also through other effects. Garlic induced activation of nitric oxide synthase may play a role in maintaining arterial elasticity.

\section{Anti-tuberculosis effect}

Bulb taken orally at variable dose levels by a group of 55 patients was active on $\mathrm{M}$ tuberculosis. Dried bulb in broth culture was active on M tuberculosis. No synergy between garlic extract and any of four antituberculous drugs is seen. Essential oil of fresh bulbs on agar plate and administered intra peritoneally to guinea pig was active on $\mathrm{M}$ tuberculosis 


\section{Antihelmentic Potential}

Development of anthelmintic resistance in helminthes reported in a number of countries, gives a clear indication that control programs based exclusively on their use are not sustainable. The development of integrated programs to control helminths is vital, but such control programs require viable alternatives to the use of anthelmintics. Medicinal plants have served through ages, as a constant source of medicaments for the exposure of a variety of diseases. The history of herbal medicine is almost as old as human civilization. The plants are known to provide a rich source of botanical anthelmintics, antibacterials and insecticides. A number of medicinal plants have been used to treat parasitic infections in man and animals. The alcoholic extract of bulb of $A$. sativum has also shown moderate in vitro anthelmintic activity against human Ascaris lumbricoldes. A. sativum has been reported to be effective in the exposure of dysentery and also act as vermifuge. Oil of $A$. sativum has also been reported to possess anthelmintic activity and discards all injurious parasites in the intestine. Garlic is the best known source of selenium. The sulfur compound allicin, produced by crushing or chewing fresh garlic, in turn produces other sulfur compounds: ajoene, allyl sulfides, and vinyldithiins

\section{Antiinflammatory Potential}

Cytokines involved in inflammatory bowel disease (IBD) direct a predominantly cell-mediated $\mathrm{T}$ helper- 1 (Th1) immune response. The nonspecific anti- inflammatory treatment being used in the management of patients with IBD has not changed much since the 1970s and new therapeutic agents are keenly sought. Several compounds isolated from Allium sativum (garlic) modulate leukocyte cell proliferation and cytokine production. To investigate the possible therapeutic effects of garlic in the treatment of patients with IBD, whole blood and peripheral blood mononuclear cells (PBMCs) were stimulated in the presence of various concentrations of garlic extract and the effect on leukocyte cytokine production was determined in vitro using multiparameter flow cytometry. By inhibiting Th1 and inflammatory cytokines while upregulating IL-10 production, treatment with garlic extract may help to resolve inflammation associated with IBD. An in vivo animal model study needs to be undertaken to determine the significance of these in vitro findings

\section{Antidiabetic Potential}

Diabetes is a metabolic disturbance that gradually affects the function of various systems in the body. Poorly controlled blood glucose is believed to be the most important factor in the development of diabetic complications in both

type 1 and type 2 diabetes. Based on report of WHO, garlic can be used for helping treatment of hyperglycemia. According to a report by Ryan et al. (2001), one-third of diabetic patients take alternative medications that they consider efficacious, of which garlic is the most commonly used. Garlic and garlic constituents prepared by various means have been shown to have antidiabetic actions.

\section{Immunomodulatory Potential}

Allium sativum an important medicinal plant having immunomodulatory effects. Three proteins showing immunomodulatory were separated from garlic by Q- Sepharose chromatography of $30 \mathrm{k}$ D ultrafiltrate of raw garlic extract. All these proteins exhibit the mitogenic activity towards human peripheral blood lymphocytes, murine splenocytes and thymocytes. P.Venkatesh et al., was isolated these immunomodulatory proteins from raw garlic, and examine their effects on the immune system (lymphocytes, mast cells and basophils) in relation to mitogenicity and hypersensitivity. The richly present garlic ImPs, QR-1 and QR-2, identified in present study as the lectins or agglutinins ASA II and ASA I, was found to be potent mitogenic activity having potential utility in therapeutic immunomodulation. Garlic has been shown to be a possible biological response modifier. First reported the augmentation of tumor immunity by garlic; subsequently a variety of immunostimulatory effects of garlic were reported. Because certain diseases can be caused by immune dysfunction, modification of immune functions by garlic may contribute to the treatment and prevention of diseases. Thus, some pharmacologic effects of garlic might be mediated through immunomodification. A unique garlic preparation, called aged garlic extract

(AGE) has been reported to have an array of pharmacologic effects, including immunomodulation. (33-35)

\section{Anticancer Potential}

A number of studies have demonstrated the chemopreventive activity of garlic by using different garlic preparations including fresh garlic extract, aged garlic, garlic oil and a number of organosulfur compounds derived from garlic. The chemopreventive activity has been attributed to the presence of organosulfur compounds in garlic. The exact mode of action was not fully understood, but several modes of action have been proposed. These include its effect on drug metabolizing enzymes, antioxidant properties and tumor growth inhibition. Most of these studies were carried out in the animal models. Also, recent research has focused 
on the antimutagenic activity of garlic. Recently, it has been observed that aged garlic extract, but not the fresh garlic extract, exhibited radical scavenging activity. The two major compounds in aged garlic, S-allylcysteine and S-allylmercapto-L-cysteine, had the highest radical scavenging activity. In addition, some organosulfur compounds derived from garlic, including S-allylcysteine, have been found to retard the growth of chemically induced and transplantable tumors in several animal models. Therefore, the consumption of garlic may provide some kind of protection from cancer development.

\section{Hepatoprotective Potential}

morbidity and mortality. Free radicals and oxidative stress have been implicated in the pathogenesis of ethanol induced liver injury in humans and experimental animals. Basically, ethanol is metabolized into cytotoxic acetaldehyde by alcohol dehydrogenase in the liver and acetaldehyde is oxidized to acetate by aldehyde oxidase or xanthine oxidase giving rise to Reactive oxygen species (ROS) via Cytp450. Thus, excess intake of alcohol resulted in the production of oxygen radicals which leads to lowering the body's normal defense mechanism thereby altered enzyme activity, decreased DNA repair and impaired utilization of oxygen, lipid peroxidation and protein oxidation. Oral administration of raw garlic protects tissue damage by increasing the antioxidant status against oxidative stress. Hence, garlic plays a promising role in antioxidant and it can be considered as a potent drug for the treatment of alcoholic disorders. Lead has been known to be environmental pollutant and its toxicity has also been associated with some health hazards. Liver enzymes such as ALT, AST and ALP are marker enzymes for liver function and integrity. These enzymes are usually raised in acute hepatotoxicity or mild hepatocellular injury, but tend to decrease with prolonged intoxication due to damage to the liver. Administration of lead showed significant increase in plasma ALT and ALP activities, and conversely decrease plasma AST activity level. Post-lead treatment with A. sativum significantly reduced the activities of ALT and ALP, and increased the activity of AST when compared to the rats treated with lead alone. The reduced serum ALT and ALP activities may generally be attributed to decreased production of these enzymes from these sources hence denotes the reversing effect of lead toxicity in rats (42-44).

\section{Expectorant:}

Lasuna has been traditionally used in respiratory conditions like asthma and bronchitis. The herb contains sulphur compounds, which contribute towards its mucolytic and expectorant properties

\section{Digestive:}

The Lasuna bulb is effective in treating dyspepsia as it stimulates peristaltic action and the secretion of digestive juices. It also relieves flatulence.

\section{Drug Interactions}

1. Antiplatelet Medications - Garlic may exaggerate the activity of medications that inhibit the action of platelet in the body including aspirin, dipyridamole \& Indomethacin.

2. Blood thinning medication - Large quantities of garlic either fresh or commonly prepared may increase the risk of bleeding including Aspirin \& warfarin.

3. Sulfonylureas - A class Diabetic medications - garlic may lower blood sugar considerably so when using garlic with these medications blood sugar level should be monitored include, Chlorpropamide, Glimeperide \& Gliburide.

4. Protease inhibitors - A medication used to treat people with Human Immuno Virus deficiency (HIV) garlic may reduce blood levels of protease inhibitors includingIndinavir, Ritanavir \& Saquinavir.

5. Statins - A class of cholesterol lowering Medication, garlic may behave similar to statins including Atorvastatin \& lovastatin.

6. ACE inhibitors - A class of blood pressure lowering medications - Garlic may behave similarly to Ace inhibitors so it is recommended not to take large quantities of garlic with any and these medications including, captopril, enalapril \& Lisinopril.

\section{Research Profile}

- Allin was found to be useful clinically in the treatment of RA (n=45).B2 pts had relief from symptoms. A change in the mucoprotein levels and ESR was observed (sreenivas murthy et al 1962).

- Allisatin $(200 \mathrm{mg} / 100 \mathrm{~g} /$ day) showed slight inhibition activity against formalin induced activities. (Prasad et al 1966) 
- The alcoholic extract and bulbs showed anti-inflammatory activity against,cara jeenan induced rat hind paw edema in albino rats (Bakunietal 1969)

- The effect of the juice of garlic on glucose utilization was studied in rabbit by using GTT.

- The hypoglycemic effect was compared with that of tolbutamide and control groups (on distilled water jain etal 1973

- Garlic juice and essential oil extract were found to have significant protective action against fat induced in serum cholesterol and plasma fibrinogen and in fibronolylic activity as well as co-coagulation time ( Bodia and Bansal 1973,Bordia et al 1974 b)

- Garlic caused marked improvement in systolic and diastolic arterial tension in 114 hypertension and atherosclerotic patients. It had beneficial prophylalchohalic action. It had definite bactericidal effect on pathogenic micro organism.(DEVT Apoth Zig 1966).

- Extract of Leaves, Stem and Bulb produced a stimulating followed by inhibitory effect on the uterus non pregnant guinea pig; conversely it produced stimulating effect on uterus of guinea pig (Jpn-J. Pharamacol 1969 19\%)

- Blood cholesterol level was significantly decreasing in all human subjects after two months of ingestion of garlic. (fnd .J. of physiology and pharmacology 1979)

- Diallyl tri sulphide showed anti microbial activity (chemical abstract 1981, $9586205 a 7$.

- Enhancement of phospolipid metabolism, initial action caused by termar promoter 12-0 tetradecanoyl pherbol-13-accetate inhibited by plant extract, it also suppressed the first step of tumor promotion in 2 stage mouse skin carcinogenesis in vivo (carcology 1989,46,2ff)

- Platelet adhesion to polycarbonate film surface was decreased by $0.05-0.5 \mathrm{ml}$ garlic oil $/ \mathrm{ml}$ of platelet rich plasma thus extracts inhibited platelet aggregation. (thranb pce 1985,37,489)

- Ajane showed strong inhibition of platelet aggregation (J.Am.Chem sec 1986, 108, 7045).

- Alicin inhibited human platelet aggregation in vitro without affecting cycl oxygenaric at throboxane synthesis activity at CAMP level (Agents action 1988, 25.182)

- 5-allyl cysterine sulphoxide showed significant anti-diabetic effect in alloxan diabetic rate (fnd.J.Biol 1992, 30,523).

- The protective effect of Allium sativum clove, aqueous and methanolic extract against hypoxia induced lethality in mice. (Phytotherpia 2003, 17 (3), pp279-281.

- Invitro susceptibility of Scedosporium prolificans to ajoene, allitridium and a raw extract of garlic. (Journal of microbiology \{2003\}, (3) pp593-597.

- Beneficial effect of aqueous garlic extract on the vascular reactivity of streptozotocin diabetic rats. (Journal of ethnopharmacology 2003, vol 3, pp 139-144.)

- Allium sativum in dose of $30 \mathrm{gm} /$ chick prevented the rise in serum cholesterol level when given along with atherogenic diet: had no effect on blood phospholipid level but significantly lowered the raised blood phospholipid level could reduce the normal serum cholesterol - PRU LHMC new Delhi.

- Garlic showed slight anti-inflammatory property against formalin induced arthritis but none against granuloma puch, no effect on adrenal glands, while betamethasone caused maximum gastric ulcer and haemmorhage but was minimum with Allium sativum. - PRU Varanasi.

- Allisatin in the form of aqueous suspension administered to rats in a dose of $200 \mathrm{mg} / \mathrm{kg}$ p. o for 15 days against formaldehyde arthritis and granuloma pouch for 6 days exhibited significant but low anti-inflammatory activity.

- Garlic capsules in a dose of one capsule 3 times a day orally for 2 months exhibited significant effect on patients with different rheumatic disorder associated with pain, tenderness, swelling, range of movement, duration of morning stiffness, grip strength. The capsule produced gastric irritation as the only side effect. - Amba et all 1981 .

- Both the juice and essential oil of garlic produced significant protective action against fat induced increased serum cholesterol and plasma fibrinogen and decreased fibrinolytic activity as well as coagulation time. - Bordia et al 1974.

- Alcoholic extract from bulbs of Allium sativum in a dose of $5 \mathrm{mg}$ of crude drug $1 \mathrm{~kg}$ p.o for 7 days increased whole blood co-agulation time, prothrombin time, fibrinolytic activity and reduction in serum cholesterol in rabbits during the first week of treatment. - Gurudeep singh and Chaturvedi 1979.

- Oral administration of aqueous extract to hyper cholestrlaemic patients for $4 \mathrm{month}$ ( $0.5 \mathrm{ml} / \mathrm{kg} / \mathrm{day})$ significantly decrease cholesterol level because of sulphur containing compound in it which could react with SH group system -Augusti 1977.

Researchers at the Hartford Hospital, Connecticut, conducted a meta-analysis study of ten recent clinical trials and found Lasuna to be supportive of normal blood pressure levels in the body (The Annals of Pharmacotherapy, December 2008, 42(12):1766-71). 
Scientists at the Department of Medicinal Chemistry, Hebrew University-Hassadah Medical School, Jerusalem, recently studied Lasuna for its antioxidant activity and support of normal cardiovascular function. They found the herb to be supportive of normal plasma lipid levels and noted its various 'positive influences' (Molecular Nutrition and Food Research, November 2007, 51(11):1365-81).

\section{Side Effects Of Garlic:}

Externally

- A stinging sensation on the skin from handling too much of fresh or dried Garlic.

- It can cause blisters if applied to delicate skin.

- Handling may also cause the appearance of skin lesions.

- Contact dermatitis (skin rash)

\section{Internally}

- Due to Garlic's blood thinning properties it should not be used by people ith bleeding disorders suh as, Hemophilia Platelet disorders

- Excess intake of garlic can cause increase risk of bleeding during or after Delivery Undergoing surgery

Hence by using the below yogas care should be taken

Yogas Of Lasuna In Sahasrayoga

\begin{tabular}{|l|l|l|l|}
\hline SI no & Name of the yoga & Indication & Reference \\
\hline 1 & Bala lashuna kandadi kashaya & Kostaka shirshaka & S.Y part I 364/73 \\
\hline 3 & Rasonadi kashaya & Sheegra vatanulomaka & S.Y part I 437/88 \\
\hline 4 & Lashunadi kashaya & Vruddi \& Udara roga & S.Y part I 451/91 \\
\hline
\end{tabular}

Sidhayoga Sangraha

\begin{tabular}{|l|l|l|l|}
\hline Sl no & Name of the yoga & Indication & Referene \\
\hline 1 & Rasonadi vati & $\begin{array}{l}\text { Ajeerna, visoochika, udarashoola,P- } 41 \\
\text { vatanulomana }\end{array}$ & $\begin{array}{l}\text { In all vata rogas, apatantraka, apasmara,P-106 } \\
\text { urusthambha udara, parshwa shoola, } \\
\text { krimiroga }\end{array}$ \\
\hline 3 & Rasona pinda & Rajaykshma, Gandamala, apachi & P-84 \\
\hline
\end{tabular}

\section{Sarangadhara Samhitha}

\begin{tabular}{|c|c|c|c|}
\hline SI no & Name of the yoga & Indication & Reference \\
\hline 1 & Rasona kalka & Vata roga, Vishama jwara & Sha.S. Madyama 5/7 \\
\hline 2 & Rasona kalka with Eranda kwatha & $\begin{array}{l}\text { Sarvanga, ekanga vata, } \\
\text { apsmara, unmade, gridrasi }\end{array}$ & Sha.S. Madyama 5/8 \\
\hline 3 & Lashunadi lepa & Dusta vrana & Sha.S. Madyama \\
\hline
\end{tabular}

Nidana Chikitsa Hasthamalaka

\begin{tabular}{|l|l|l|l|}
\hline SI no & Name of the yoga & Indication & Reference \\
\hline 1 & Rasonadi vati & Visoochika & Part-II, $7^{\text {th }}$ chapter/176 \\
\hline 2 & Lahunadi vati & $\begin{array}{l}\text { Visoochika, } \\
\text { Agnimandya, Ajeerna \& gulma }\end{array}$ & Part- II $4^{\text {th }}$ chapter \\
\hline 3 & Lashuna,Shunti,Nirgundi kwatha & Amavata & Part - II/646 \\
\hline
\end{tabular}

Susrutha Samhitha

\begin{tabular}{|l|l|l|l|}
\hline SI no & Name of the yoga & Indication & Reference \\
\hline 1 & Shirovirechana dravyas & Urdva jatrugata vikaras & SSU39/6 \\
\hline 2 & Katurasa varga & Sarasaradi varga & SS Su 42/11 \\
\hline 4 & Shakavarga & As aharadravya & SS Su46/221 \\
\hline 5 & Sthanyajana Dravya & Sthanya Jananartha & SS Sha10/30 \\
\hline 6 & Manhanjana & Shlesmabhishyanda & SS U 11/9 \\
\hline 7 & Lashunadi Taila & Rakthabhishyanda & SS U 12/25 \\
\hline 8 & Lashunadi swarasa & karnavedana & SS U 21/15 \\
\hline
\end{tabular}


Critical Analysis of Lasuna (Role of Lasuna in Different Branches of Ayurveda)

\begin{tabular}{|l|l|l|l|}
\hline 9 & Suradi taila & Kaphaja karna shoola & SSU 12/32 \\
\hline 10 & Lashuna poothi keeta churna & Ghrana Hikka & SS U 50/23 \\
\hline 11 & Shireesha Bhejadi yoga & Bhootavidya & SS U 60/43 \\
\hline 12 & $\begin{array}{l}\text { Lashuna,Hingu,Sarshapa, } \\
\text { puranasarpi3 }\end{array}$ & Vacha & Visha chikitsa \\
\hline 13 & Brahmatyadi yoga & Unmada & SS U 62/30 \\
\hline 14 & Lashunadi yoga & Shosha roga & SS U41/57 \\
\hline 15 & Rasonadi gritha & Gulma,Grahani,Shwasa, Unmada & SS U 42/31 \\
\hline & Shakavarga & As Aharadravya & SS Su 46/221 \\
\hline
\end{tabular}

\section{Bhavaprakasha}

\begin{tabular}{|c|c|c|c|}
\hline SI no & Name of the yoga & Indication & Reference \\
\hline 1 & $\begin{array}{l}\text { Shigru, kasta, Jeeraka \& } \\
\text { Lashunawith taila }\end{array}$ & Apasmara & BPII 23/23 \\
\hline 2 & $\begin{array}{l}\text { Lashuna kalka with Saindhava } \\
\& \text { tila }\end{array}$ & Hanugraha & BPII 24/28 \\
\hline 3 & Lashunadi yoga & Hanugraha & BP II 24/29 \\
\hline 4 & Lashuna kalka with tila & Arditha & BPII 24/74 \\
\hline 5 & Rasona kalka & Vataroga Vishama jwara & BP II24/344 \\
\hline 6 & Rasonastka yoga & $\begin{array}{l}\text { Sarvangavata,Arditha, } \\
\text { ApatantrakaApasmara,Unmada }\end{array}$ & BPII24/348 \\
\hline 7 & Rasonadi kashaya & Amavata & BPII26/39 \\
\hline 8 & Rasona pandam & Amavata,Vataraktha, Sarvanga \& Ekanga vata & BPII 26/112 \\
\hline 9 & Lashuna taila & $\begin{array}{l}\text { Udararoga, Mootrakricchra, udavartha, } \\
\text { Antravruddi, Shoola }\end{array}$ & BPII 41/36 \\
\hline 10 & $\begin{array}{l}\text { Lashuna, madhu, laksha, gritha, } \\
\text { sita }\end{array}$ & ,Chinna, bhinna, Chyutha and Bhagna & BP II 48/27 \\
\hline 11 & Lashuna, Ardraka & Karnashoola & BPII64/13 \\
\hline 12 & Garlic tincture & Laryngitis & BPII \\
\hline 13 & Lashuna avalehya & Kasa,Swarabheda,dyspnoea & $\mathrm{BP} \mathrm{I} / 130$ \\
\hline 14 & $\begin{array}{l}\text { Lashuna ksheera paka with } \\
\text { vidanga }\end{array}$ & Vata vyadhi & BPI \\
\hline 15 & Lashuna taila & Vatavyadhi & BP I \\
\hline 16 & Lashuna Phanta & Vatavyadhi & BP I \\
\hline 17 & Lashuna swarasa & Apatantraka & BP I \\
\hline 18 & Lashuna swarasa with Dugdha & Round worms & BP I \\
\hline 19 & Lashuna gritha & Vata gulma, duodenal ulcer & BP I \\
\hline 20 & Garlic tincture with Lime & Antraka jwara, Vishamajwara & BP I \\
\hline 21 & Lashuna swarasa with jala & Vrana & BP I \\
\hline
\end{tabular}

\section{Yogaratnakara}

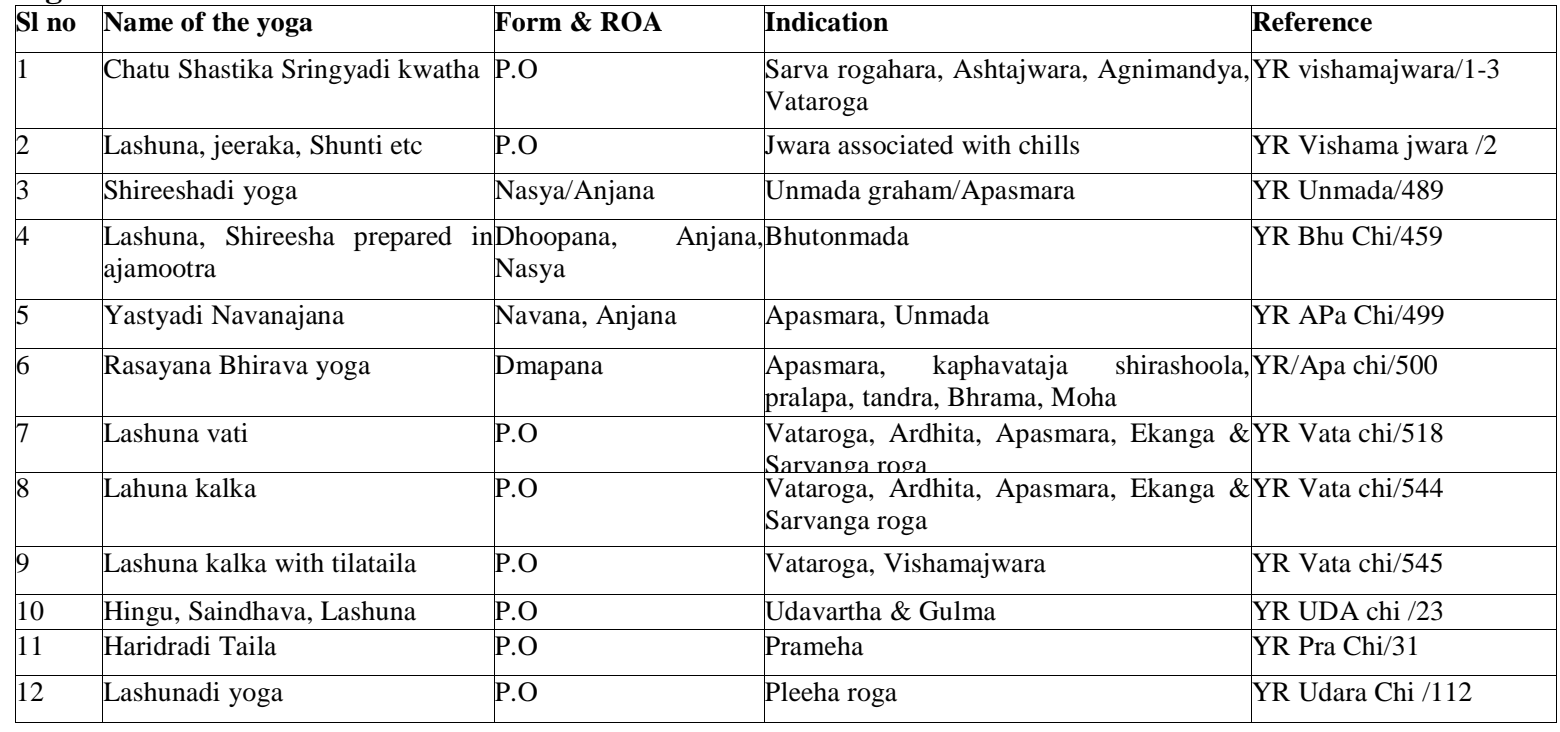


Critical Analysis of Lasuna (Role of Lasuna in Different Branches of Ayurveda)

\begin{tabular}{|l|l|l|l|l|}
\hline 13 & Rajika with Lashuna & Lepa & Galagranthi & YR Gra chi/154 \\
\hline 14 & Rasonadi yoga & P.O & Bhagna & YR Bhagna chi/191 \\
\hline 15 & Lashunadi swarasa & Karna poorana & Karnashoola, Bhadirya & YR karna chik/313 \\
\hline
\end{tabular}

\section{Chakradatta}

\begin{tabular}{|l|l|l|l|l|}
\hline SI no & Name of the yoga & Form \& ROA & Indication & Reference \\
\hline 1 & Rasona kalka with a tila taila & P.O & Vishamajwara, Vatavyadhi & Visa.jwa.Chi/214 \\
\hline 2 & Lashunadya Ghritha & P.O & $\begin{array}{l}\text { Unmada, Shoola, Arshas, Udara, Unm.chi/40 } \\
\text { pandu }\end{array}$ & Vat. Vyadhi/149 \\
\hline 4 & Rasona Tailam & P.O & $\begin{array}{l}\text { Amavata, Sarvanga \& Ekangavata, Ama.Chi/64 } \\
\text { Apasmara, Unmada }\end{array}$ \\
\hline 5 & Rasona sura & P.O & $\begin{array}{l}\text { Vataroga, Ama, Krimi, Kusta Kshaya, Ama.Chi/71 } \\
\text { Gulma, Arshas, Pandu }\end{array}$ & Shool.chi /71 \\
\hline 6 & Lashuna kalka with Madya & Licking & Agnideepana, Vatika shoola & $\begin{array}{l}\text { Vataja gulma, Udavartha, Gridrasi, Gul.chi/10 } \\
\text { Vishamajwara, Hridroga }\end{array}$ \\
\hline 8 & Rasona saditha ksheera & P.O & $\begin{array}{l}\text { Gulma, Grahani, Arshas, Unmada, Gul.chi/83 } \\
\text { Kshaya, Jwara }\end{array}$ & Plee, yakru.chi/10 \\
\hline 9 & Rasonadya gritham & P.O & Yakruth, pleeha roga & P.O \\
\hline
\end{tabular}

Siddha Bheshaja Sangraha

\begin{tabular}{|l|l|l|l|l|}
\hline Sl no & Name of the yoga & Form \& ROA & Indication & Reference \\
\hline 1 & Lashunastaka churna & P.O & $\begin{array}{l}\text { Visoochika, Agnimandya, Ajeerna, } 1 \text { st } \\
\text { Udara }\end{array}$ & $\begin{array}{l}\text { Visoochika, Agnimander/32 } \\
\text { Udara }\end{array}$ \\
\hline 2 & Rasonadi vati & P.O & $\begin{array}{l}\text { Udararoga, Yakruth rga, Udavartha, } \\
\text { Antravruddi }\end{array}$ & th chapter/59 \\
\hline 3 & Rasonadi taila & P.O & chapter/167 \\
\hline
\end{tabular}

Bhaishajya Ratnavali

\begin{tabular}{|c|c|c|c|c|}
\hline SI no & Name of the yoga & Form \& ROA & Indication & Reference \\
\hline 1 & Rasona with maricha & Nasya & $\begin{array}{l}\text { Sleshmastana sthita kapha nashana in } \\
\text { sannipataja jwara }\end{array}$ & B.R 5/226 \\
\hline 2 & Shireesha, gomutra, lashuna, pippali & Anjana & Moorcha & B.R 5/236 \\
\hline 3 & Lashuna shunti with ajamutra & Nasya & Sannipata jwara & B.R 5/285 \\
\hline 4 & Rasona kalka with tilataila & Kalka & Vishama jwara, Vatarogas & B.R 5/378 \\
\hline 5 & Rasona kalka with gritha & Kalka P.O & Jwara & B.R 5/381 \\
\hline 6 & Mohandasoorya rasa & Nasya & Jwara, Tandra, Murcha, Pralapa & B.R 5/594 \\
\hline 7 & Lahuna ksheera & Panartha & $\begin{array}{l}\text { Vatika gulma, Udavartha, Gridrasi, } \\
\text { Vishamajwara }\end{array}$ & B.R 32/13-15 \\
\hline 8 & Lahunadi gritham & P.O & $\begin{array}{l}\text { Gulma, Arsha, Udara, Bhagna, Pandu, } \\
\text { Pleeha, Yonidosha, Krimi, Jwara }\end{array}$ & B.R 24/59 \\
\hline 9 & Rasona panda with Eranda moola kwatha & P.O & Vatarogas, Sarvanga roga, Ekanga vata, & B.R 26/93 \\
\hline 10 & Rasonadya gritha & P.O & $\begin{array}{l}\text { Gulma, Sangrahani, Arsha, Shwasa, } \\
\text { Unmada }\end{array}$ & B.R32/166 \\
\hline 11 & Rasona panda mahan & P.O & Amavata & B.R29/41 \\
\hline 12 & Rasona pinda & P.O & $\begin{array}{l}\text { Amavata, } \\
\text { Ekangavataroga, Apsmara, Mandagni, } \\
\text { Bhagna }\end{array}$ & B.R29/135 \\
\hline 13 & Rasonadi kwatha & P.O & Amavata & B.R 29/23 \\
\hline 14 & Rasonadi Tailama & P.O & Vatavyadhis & B.R26/26 \\
\hline 15 & Swalpa Rasona Pinda & P.O & $\begin{array}{l}\text { Ekanga roga, Sarvanga roga, } \\
\text { Urusthabha, gridrasi, }\end{array}$ & B.R 26/93 \\
\hline \multirow[t]{2}{*}{16} & Lashunadya gritham & P.O & Unmada, Shoola, gulma, & B.R 24/56 \\
\hline & & & Arshas, Udararoga, Pandu, Pleeha & \\
\hline 17 & Rasonadi yoga & P.O & $\begin{array}{l}\text { Udara, Mutrakricchra, Udavarta, } \\
\text { Antravriddi }\end{array}$ & B.R 40/151 \\
\hline 18 & Lashunadi prayoga & P.O & Pleeha, Yakruth roga & B.R 41/62 \\
\hline 19 & Rasonadi yoga & P.O & Chinna, Bhinna, Chyutha, Bhagna asthi & B.R 49/10 \\
\hline
\end{tabular}


Critical Analysis of Lasuna (Role of Lasuna in Different Branches of Ayurveda)

\begin{tabular}{|c|c|c|c|}
\hline 20 & Kusta rakshasa taila & P.O \& Ext & $\begin{array}{l}\text { Kusta, Switra, Kachhu, Mamsavruddi,B.R 54/294 } \\
\text { Bhagandara, Vicharchika, Pama }\end{array}$ \\
\hline 21 & Lashunadi swarasa & Karnapoorana & Karnashoola \\
\hline 22 & Lashunadya tailam & Karnapoorana & Karnabhadirya \\
\hline
\end{tabular}

\section{Role of Garlic In Shalya Tantra}

- Colon cancer, rectal cancer. Research suggests that eating garlic can reduce the risk of developing colon or rectal cancer. Research suggests that taking high doses of aged garlic extract daily for 12 months reduces the risk of developing new tumors. However, other garlic supplements do not seem to offer the same benefit.

- Wound Healing Potential Successful wound healing depends upon angiogenesis, and impaired angiogenesis is a hallmark of the chronic wounds encountered with diabetes and venous or arterial insufficiency. To intervene and improve wound closure, it is essential to investigate the effects of different natural remedies in wound healing. Study was done on the chicken dorsum skin excision wound assay to investigate the influence of different concentrations of aged garlic solution (AGS) on wound healing. Gross, histopathology, scanning electron microscopy (SEM) and computer-based three-dimensional (3D) imageprobing techniques were utilized to determine the effects of AGS on wound closure, re-epithelialization, dermal matrix regeneration, and angiogenesis

- Anticoagulant and Fibrinolytic Potential Over the century garlic (allium sativum) and other species in the genus allium have enjoyed an important reputation as the prophylactic and therapeutic agent. Of these, the usefulness of garlic in preventing disease of cardiovascular system is widely recognized. There are several report on anticoagulant. Song et al (1960) have isolated blood anticoagulant substance from garlic and studied its physical and chemical properties. A half $\mathrm{mg}$ of garlic extract completely inhibited one $\mathrm{ml}$ of blood from coagulating. The inhibiting effect of garlic extract on blood clotting was almost the same as that of potassium oxalate so used in DPT, Venous and arterial ulcer.

- Benign prostatic hyperplasia (BPH). There is some early evidence that taking garlic by mouth might be helpful for improving urinary flow, decreasing urinary frequency, and other symptoms associated with $\mathrm{BPH}$.

- Surgery: Garlic might prolong bleeding. Stop taking garlic at least two weeks before a scheduled surgery.

- Antimicrobial Potential The antibacterial properties of crushed garlic have been known for a long time. Various garlic preparations have been shown to exhibit a wide spectrum of antibacterial activity against Gram-negative and Gram-positive bacteria including species of Escherichia, Salmonella, Staphylococcus, Streptococcus, Klebsiella, Proteus, Bacillus, and Clostridium. Even acid-fast bacteria such as Mycobacterium tuberculosis are sensitive to garlic. Analysis of steam distillations of crushed garlic cloves performed over a century ago showed a variety of allyl Sulfides isolated and identified the component responsible for the remarkable antibacterial activity of crushed garlic cloves. The compound turned out to be an oxygenated sulfur compound which they termed allicin from the Latin name of the garlic plant, Allium sativum

- Antifungal Potential Garlic (Allium sativum) is an intriguing herb with alleged powers ranging from warding off vampires to the more recently reported power of curing fungal infections. Fungal infections have become an important aspect of modern infectious disease practice. The prominence of fungi as pathogens may be due to the longer survival of immunocompromised patients, the recent development and usage of broader-spectrum antibiotics, or the wider use of immunosuppressive and cancer chemotherapeutic agents. High dilutions of extracts of Allium sativum, or garlic, have been shown to possess fungistatic and fungicidal activity in vitro and in vivo. In the People's commercial A. sativum extracts are wi.dely used to treat patients with systemic fungal infections. In support of the use of A. sativum to treat cryptococcal meningitis, researcher found anti-Cryptococcus neoformans activity in plasma and cerebrospinal fluid (CSF) following intravenous (I.V.) administration of a commercial A. sativum extract. Allium sativum, had the best activity against the three Candida albicans. The antifungal activity of six fractions derived from garlic was investigated in an in vitro system. Ajoene had the strongest activity in these fractions. So it is to be used in infective dermatitis and woundhealing purpose.

- Prostate cancer. Men in China who eat about a clove of garlic daily seem to have a $50 \%$ lower risk of developing prostate cancer. However, research in Iranian men suggests that eating garlic has no effect on prostate cancer risk. Whether this research applies to men in Western countries is not known. Some early research suggests that taking garlic supplements might reduce the risk of developing prostate cancer or reduce symptoms associated with prostate cancer.

- Hardening and tightening of the skin and connective tissue (scleroderma). Research suggests that taking garlic daily for 7 days does not benefit people with scleroderma. 
- Warts. Early evidence suggests that applying a specific fat soluble garlic extract to warts on the hands twice daily remove warts within 1-2 weeks. Also, a water-soluble garlic extract seems to provide modest improvement, but only after 30-40 days of treatment.

- Hair loss (alopecia areata). Early evidence suggests that applying a garlic 5\% gel, along with a topical steroid, for 3 months increases hair growth in people with hair loss.

- Garlic has a major role in reducing Hiatal hernia as a dietary supplement.

- Vascular Effects: Vasorelaxant properties of garlic have been noted in multiple pre-clinical studies. Cutaneous microperfusion is increased in humans following ingestion of $600 \mathrm{mg}$ of garlic and vasodilation of conjunctival arterioles and venules occurs at $900 \mathrm{mg}$. Garlic may act on the nitric oxide system and exert effects on the elastic properties of vasculature yielding changes in systemic b.p. It has been suggested that allicin is the component of garlic responsible for nitric oxide-mediated effects. Prostaglandins have been identified in garlic extracts which may exert pharmacologic effects although this has not been demonstrated in vivo.

- Genitourinary Effects Chronic garlic ingestion for 70 days has been associated with suppression of spermatogenesis in rat

- Chemoprotective /Anti-tumor Effects: Animal studies have reported protective effects of garlic against hepatotoxins cyclophosphamide, adriamycin methylcholanthrene, gentamicin 4-nitroquinoline 1-oxide and bromobenzene. Garlic has demonstrated strong inhibition of cancer development in the presence of known tumor promoters including 12-O-tetradecanoylpharbol-13-acetate and 7,12-dimethylbenzanthracene and phorbol-myristate-acetate, as well as tumor inducers such as 7,12-dimethylbenzanthracene and 1,2dimethylhydrazine There is some evidence that the chemical constituents containing allyl groups may be responsible for chemoprotective properties. Research has provided evidence of anti-proliferative effects of garlic on human cancer cell lines including induction of apoptosis, regulation of cell cycle progression and signal transduction modification. Both cellular proliferation and immune function appear to be affected.

- It is mainly used in treating the athlete's foot because of its anti fungal and anti- bacterial activity.

\section{Role Of Garlic In Prasuthi Tantra}

- Garlic and Vaginosis

Even though in vitro studies demonstrate that garlic has antibacterial properties, most research on its effectiveness in treating vaginosis is inconclusive. According to a May 2003 review of alternative medical treatments published in the "Obstetrical \& Gynecological Survey," garlic is indeed widely used to treat vaginosis, but there is a lack of good-quality studies demonstrating its effectiveness. In the authors' opinion, more randomized, controlled clinical trials are needed before doctors can recommend this substance for the condition. It controls vagina yeast.

- It lowers the B.P in pre-eclampsia patient and it prevent the complications of pre-eclampsia.

- Garlic is one of the main ingredient in niruhavasthi is done after uttaravasthi for the treatment of vandhya .In this lasuna is vata hara and srothosodhaka due to its theekshna guna. By its tikshna guna it acts as srothosodhaka, removes the block \& help for the conception.

- Take garlic to boosts the weight of babies in the womb. Some babies are born too small, so garlic is a definite boon in these cases too.

- A Research study was conducted to evaluate the efficacy of uttaravasthi with trivrith and lasuna oil in primary dysmenorrhea.Lasuna has anti- spasmodic, Anti- inflammatory activity and trivrith is sukavirechaka.On the basis of above facts, it may be concluded that the drugs Rasona and Trivrit are effective in spasmodic dysmenorrhea without causing any side effects.

- Menopause is associated with an increase in oxidative stress and a decrease in some antioxidant parameters. Consumption of garlic extracts and crude black seeds may have a beneficial effect on improved balance between blood oxidants and antioxidants in healthy postmenopausal women.

- It plays main role in oxidative stress related to male infertility. It relaxes smooth muscles, dilates the blood vessels, stimulates the immunity while inhibiting the antibody reactions improves selenium absorption, reduces the oxidative stress.

- Garlic has anti- aging benefits and skin smoothing benefits by enhances blood flow thus giving the skin a natural glow

- Due its anti-fungal property it reduces the Acne, pimples.

- During the pregnancy garlic may help to treat poor blood circulation and elevated blood pressure.

- Don't take garlic before going to surgery.

- Garlic is great warding off clots, which is use fantastic because during pregnancy your immune system is suppressed, leaving you more susceptible to getting sick. 
- It prevents the miscarriage. It prevent the clots and thing the blood improve the blood circulation from placenta to baby.

\section{Role Of Garlic In Salakya Tantra}

- To use garlic for relieving throat infection pain, simply suck on a small slice for about 15 minute.

- It is useful in upper respiratory infections like bronchitis, Pharyngitis, Rhinopharyngitis.

- Cold, Flu, Fever, sore throat, tonsillitis, mouth ulcers, sinusitis are treated by lasuna.

- For ear infection: Cut a small tube, or plug shape piece of fresh garlic bulb, wrap that piece in tissue, place the wrapped garlic into the ear canal. Don't shove it down in there deeply, you just want it resting in the opening like an ear plug. Infection completely gone within $24-48 \mathrm{hrs}$.

- Garlic oil is an easy made, natural remedy to treat earache and ear infection. You can try the following methods to get relief from the earache and ear infection. It helps to soothe the wax that buildup in the ear, reduces the pain and infection slowly when used regularly.

- Take few garlic cloves and mash them properly Cover these mashed garlic in a cloth and dab to pour liquid from garlic cloves into the infected ear. This garlic juice helps to treat ear pain and infection.

- Take a teaspoon of mustard oil or sesame oil, Heat the oil by adding $2-4$ cloves of garlic for few minutes until the oil gets lukewarm and oil turns to black. Let the oil cook for few minutes and then apply this oil around your ear.You can also pour few drops of this oil inside your ear to get rid of the pain.

\section{- (Boiled Garlic Cloves with Salt)}

Take $3-5$ garlic cloves and boil them in water for $5-7$ minutes, Remove it from the heat and crush it by adding a little bit of salt, Mix it and put it in a cloth and place this cloth against affected area for few minutes, Repeat the process continuously to get quick relief from the pain and infection.

\section{- (Garlic Clove with Cotton or Gauze)}

Take a clove of garlic and cut any of its edge and peel off the skin, Boil it for few minutes and place it on the ear (but don't push deep into the ear canal) or you can use raw garlic clove, Cover it with a cotton ball or gauze and leave it for that day without disturbing it. Take it out in the next day and repeat it if needed. This process aids in pulling out the infection.

\section{- (Garlic with St. Johnswort Oil)}

Take half garlic, half St. Johnswort oil and small amount of mullein oil, Add all these ingredients in 3 drops of grapefruit seed extract and mix it well. Apply this by using an ear dropper to pour it in the affected ear that aches.Leave it like that and repeat it twice a day to get quick relief from the ear ache and ear infection.

- Garlic in sore throat: This pungent bulb is thought to have "tremendous immune-stimulating effects" as well as antimicrobial (read: virus-fighting) and antibacterial qualities, says Finkelstein. So it may help the body to heal the infections that cause a sore throat while fighting the germs that cause the pain and the irritation. The compound that may be responsible for this is allicin, which is released when raw garlic is cut, crushed, or chewed. Finkelstein suggests microwaving one or two cloves for 10 to 15 seconds to decrease the intensity of the taste, then crushing them in a press and eating the garlic on a cracker. Do this once daily.

- Garlic may help you get rid of strep throat and the irritating symptoms caused by the bacterial infection. Strep throat causes a painful, itchy throat, often accompanied with a fever. You might have red spots on the roof of your mouth, and your tonsils might swell. The Mayo Clinic says strep throat symptoms are more severe than symptoms associated with other types of bacterial infections that cause a sore throat. Hang in there. Your pain won't last much longer after drinking some homemade garlic tea.

- Garlic is a powerful antioxidant with antimicrobial, antiviral and antibiotic properties. For colds and flus, it also provides decongestant and expectorant effects. While none of garlic's components have been isolated by science as the sole explanation for garlic's flu-busting effects, vitamin C, a slew of enzymes, and minerals such as sulphur and selenium, definitely play a role.

- Crushing fresh garlic - whether through chopping and letting minced garlic rest, or by chomping down on a clove with your own teeth - causes a chemical reaction that releases allicin. Allicin is a powerful antibacterial only present shortly after garlic is crushed and before it is heated! Eating fresh garlic in this state is purported to knock out that terrible feeling associated with the onset of a cold or flu. Some experts even recommend eating a clove or two every 3 to 4 hours until the bug is entirely knocked out!

- Use of garlic in sinusitis Garlic contains a number of unique sulfur compounds including allicin that make garlic an effective antibiotic and anti-inflammatory. When used as a home treatment, garlic naturally relieves swelling in the nasal passages, thus maximizing the flow of mucus in the sinus cavity and eliminating infection. Recent studies have shown the ability of diallyl trisulfide, a component in garlic oil, to protect the heart during and after cardiac surgery. Another garlic compound, diallyl sulfide, was found to be over 100 times more effective against theCampylobacter bacterium than two popular antibiotics. This 
bacterium is one of the most frequent causes of infections in the intestines. Garlic's effectiveness against this bacterium could have tremendous disease-reducing benefits to the food supply and the environment.

- Garlic can be used as an effective health remedy in a variety of ways. One of the most effective and functional treatment options involves crushing the garlic and using it as a spread. To do so, chop or mince the garlic, allow it to rest for a short period. Mix the garlic with honey and take as a paste or spread it on a piece of toast.

- Use of garlic in nasal polyp: Garlic has enormous medicinal qualities which are of great use in the treatment of a multitude of diseases and disorders. Its antibacterial, anti-inflammatory and antioxidant properties destroy infections, stimulate circulation and dissolve the accumulated mucous.

- Garlic \& shiras :More than $90 \%$ of chemotherapy patients also die within 10-15 years after treatment of Brain cancer. For the first time, organo-sulfur compounds found in garlic have been identified as effective against glioblastoma, and may soon offer effective, non-invasive forms of cancer therapy without the deadly side effects associated with chemotherapy.

- Swapan Ray, Ph.D.(MUSC Neurosciences/Neurology associate professor), Naren Banik, Ph.D. (MUSC Neurosciences/Neurology professor), and Arabinda Das, Ph.D. (MUSC Neurosciences/Neurology postdoctoral fellow) studied three pure organo-sulfur compounds (DAS, DADS, and DATS) from garlic and the interaction with human glioblastoma cells.

- The sulphone hydroxyl ions in garlic can actually penetrate the blood-brain barrier.

- A breakdown of allicin appears to be necessary for achieving maximum tumor inhibition. Allyl sulfur compounds preferentially suppress neoplastic over non-neoplastic cells (Sakamoto, Lawson, and Milner 1997).

- Garlic-derived organo-sulfur compounds are small molecules that would not necessarily require complicated methods of delivery for treating brain tumor patients, the scientists said, and their natural origin would be significantly better for the human body than synthetic treatment options.

- To take advantage of any potential anti-cancer benefits from garlic now, certain rules apply. Ray said to cut and peel a piece of fresh garlic and let it sit for fifteen minutes before eating it. This time allows for the release of an enzyme (allinase) that produces the anti-cancer compounds.

\section{Role Of Garlic In Kowmarabrithya}

- While using garlic to treat children for various ailments appears to be generally safe, more research needs to be done on its specific effects, and garlic is not recommended in at least one treatment, researchers found after reviewing several studies that used the plant to treat several childhood ailments. Their findings were published recently in Pediatrics in Review.

- The data review revealed that garlic tablets did appear to aid upper respiratory tract infections, resulting in a 1.7-fold reduction in morbidity compared with placebo and 2.4-fold reduction versus dibazole, a commercial parasiticide containing medication. Garlic applied briefly to warts also proved effective with resolution reported in all children after three to nine weeks of treatment.

- A naturopathic eardrop preparation of garlic and three other herbs was as effective as a conventional eardrop with proven pain-relieving effects for treating pain associated with ear infections in children. However, it was unknown how much the garlic itself contributed to the pain relief.

- There were no significant improvements when using garlic to treat cardiovascular disease in youngsters, and more study is needed to explore the plant's effects on b.p and lipid concentrations in children at cardiovascular risk.

- As with conventional medical treatments, there is potential for adverse effects with garlic use, Dr.Vohra (ped) said. Adverse effects of garlic described in adult and pediatric studies were generally minor, with garlic's pungent smell on both the breath and body being the most commonly reported, but the most serious adverse effect of garlic was associated with topical use. Three pediatric studies reported second-degree burns when raw, crushed garlic was directly applied to children's skin as an antipyretic or antiviral treatment. Vohra cautions parents against applying garlic directly to the skin as a topical medication.

- Warm infestation Ringworm can be treated with the use of fresh minced garlic and a loose non-stick dressing for 1-2 hours only, daily for 14 days. If the fresh garlic is too painful, try applying garlic tincture daily and covering with a non-stick dressing for 14 days. The garlic tincture does not have to be removed after 1-2 hours. Ringworm infections can take a long time to heal, continue treatment for at least one week after the infection appears resolved.

- For use of garlic in small children, it is best to simply rub raw crushed garlic on the bottoms of their feet and then apply socks for any purpose.

- Parents often wonder when is the correct time to introduce certain foods, like garlic, to their baby. We know that our children should start with bland, basic foods to get them used to new tastes and textures and not 
overwhelm them. But what about adding a little bit of flavor to their food? When can your child enjoy the seasonings you do?

- After your baby has started solid foods, usually around four to six months of age, they can start trying other foods instead of the usually fruits and vegetables. Around eight to nine months of age, babies can start receiving foods that have been flavored and are not so bland, including garlic.

- There are many benefits of garlic. Garlic is known to help your body fight infection. Some people even use it when they catch a cold. Garlic contains a compound called allicin. This compound gives garlic its potent odor and contains antibacterial and antiviral properties, which is why people use it when they get sick.

- Garlic is also known to be an anti-inflammatory agent. These properties are believed to help prevent arthritis and reduce symptoms related to asthma. Some people even believe that eating a good dose of garlic can protect the body from certain cancers. Again, it is the allicin found in garlic that is believed to fight against cancer.

- Garlic is also great for your heart. Eating garlic regularly has shown to reduce bad cholesterol levels, lower b.p and reduce the risk of strokes and heart attacks.

- It is best to introduce a small amount of garlic to your baby during the initial introduction. Some garlic may be more potent than others and may hurt your baby's stomach. Like with any food, garlic should be introduced to your baby at the right time. After the initial introduction, watch for signs of a food allergy. It is recommended to wait at least three days before introducing another "new" food to your child. Typical signs of an allergic reaction can include swelling, cramping, rash, diarrhea or vomiting. Milder symptoms should result in a phone call to your child's doctor right away. If your baby seems to be having trouble breathing, or is showing any symptoms that are more sever in nature, then approach nearby hospital.

- Garlic has also been used medicinally for over a thousand years. It is even noted as being used by people in the Bible. These ancient uses were for things like respiratory problems, parasites, low energy and poor digestion. Garlic is alleged to help regulate blood sugar levels, boost testosterone levels, prevent scurvy and remedy digestive disorders and fungal infections.

- Garlic is also believed to have religious and/or spiritual powers. It has been used as protection against white magic and some people believe it will keep them safe from demons, werewolves and vampires. In both Jainism and Hinduism religions, garlic is believed to increase one's desires, and some Buddhist religions think it is known to increase both aggressiveness and sex drives.

- Remember, garlic is perfectly safe for your baby to consume around seven months of age. It has many health benefits, and should be chopped up before giving it to your baby. Garlic should be added to your child's food and not given directly, as it is too hard for your baby to chew and may pose as a choking hazard.

- All other remedies which are previously described, also applicable to children with low doses.

\section{Role Of Lasuna In Rasayana \& Vajeekarana}

Rasona is not only valuable spice but due to prophylactic as well as curing effects, it is popular rasayana medicine. It is especially beneficial to those exposed to severe cold and who suffer from stiffness, numbness and crooked position of the body. There is no other better drug than rasuna, for persons suffering from all kinds of avarana vata excepting those by pitta and rakta and diseases caused by suddha vata (vata not associated with other dosas). Rasona Kalpa used properly for long time increases the strength of digestive fire, bestows good voice intellect, beauty, good qualities, desired children and purity of the seed in both man and woman. Nirukti of lasuna its self says that it is powerful Rasayana.

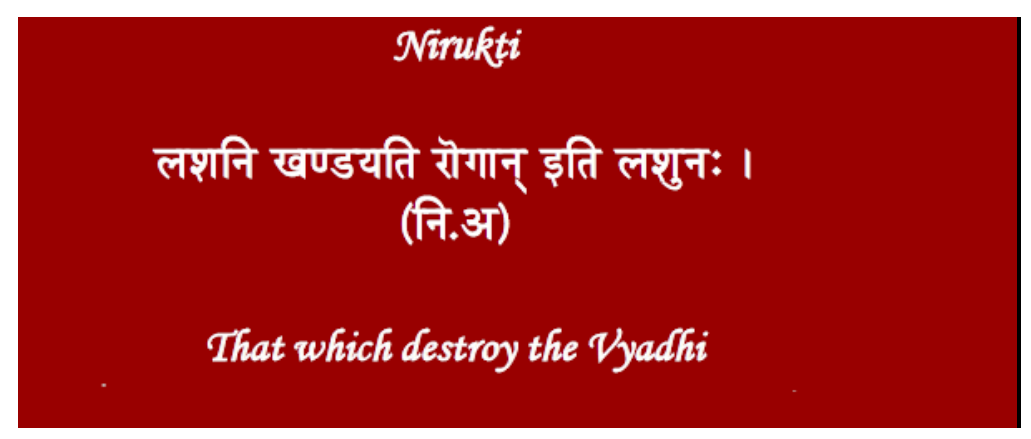

Important way of use of lasuna (garlic) as rasayana

- The rasona paste mixed with equal amount of ghee is put into a pot churned well can be consumed for ten days. It may be also consumed with equal quantity of muscle fat 
- Fresh paste of Rasona mixed with ghee or its juice with ghee may be used followed by drinking fruit juice, butter milk, sour beverage, and juice of meat of animals of desert like lands, fermented wash of barley husk or thin gruel with no solid grains or with lukewarm water

- Paste of rasona added equal amount of sasamum oil and vinegar kept hidden in a heap of barley for one year. Used later by the person who partakes meals with more, of ghee and meat cures diseases caused by vata.

- One tula (hundred pala) each of seasame oil, ghee, jaggery and sugar, two tula of husked lasuna, three kudava of tryusana (marich,sotha and pippali) one pala of tvak, are all made into a nice paste, put into a pot smeared inside with ghee and kept hidden in a heap of barley for two years, taken out later and used, this is more effective for treatment of diseases caused by vata

- One tula of paste of bulbs (of lasuna) is added to twenty pala of takra (buttermilk) and kept for seven days. Next half-tula of black tila washed well and crushed is added to the liquid along with four pala each of honey, ghee and sunthi, and one pala each of ajaji, chavya, dhanyaka, agni the two krsna, granthi, dipyaka and caturjata-powdered nicely, eight pala each of oil, ghee and crushed sarsapa, one aksa each of the five patu, two ksara are also added to the liquid, churned well and kept undisturbed for eleven days, Later on, used in the mornings daily, the person derives all the benefits of rejuvenator therapy andlives long without any disease

- Paste of lasuna one adhaka in quantity is added to one nalvana (drone) of decoction the two panchmula drugs and kept buried for one year used later it curses all diseases caused by aggravated vata and kapha.

- Juice taken out form its bulbs (of lasuna) mixed either with ghee or oil is cooked and used according to one's habituation. This cures even troublesome diseases caused by powerful vata.

- Its paste mixed with equal quantity of butter should be consumed by the patient of facial palsy

- Dehusked rasona is inserted into a piece of meat which is held by an iron rod and roasted in fire, this meat should be consumed along with different kinds of sauce/pickles etc, or crushed rasona may be consumed with ghee and sukta (vinegar) followed by partaking ordinary meal as much as desired. Soup prepared with kustumburu, jiraka and fried mudga, added with nice powder of sauvarcala, tender shoots of rasona and sauces of many tastes, may be consumed together with soups, milk and meat soup prepared form appropriate drugs in diseases suspected as caused by kapha, pitta and vata respectively.

- Person suffering from emaciation should consume rasona along with the powder of asvagandha, he who has loss of voice along with madhuyasti, he who has $\backslash$ tumors of the abdomen along with tail (sesame oil) the patient of leprosy with khadira, the patient of worms (intestinal parasites) along with krimighna. Rasona cures consumption when consumed along with meat of carnivorous animals, used with bark of kutaja it cures piles, and with srestha (triphala) it cures diabetes, cough, dyspnoea and indigestion.

- One prastha of juice of lasuna, thirty two prastha of tila taila, eight prastha of residue of kinva, eight prastha of pista (flour of rice) and yava and six prastha of mesasringi are boiled together and decoction reduced to one drone. After it cools it is put into a pot smeared inside with fat (ghee or oil) and kept undisturbed for a fortnight. After wards four prastha of pista (rice flour) is again added to it.

- This sura (beer) should be consumed by patients of diseases of vata origin. A cow which is made to fast for three days is fed with lasuna from the fourth day. The milk, curds, buttermilk and ghee obtained from the cow is ideal/ acceptable even for the Brahmans.

- Lasuna (Garlic -Allium sativum) - acts as a meda dhatu rasayana. Ayurveda M.D Journal.

\section{Precaution during lasuna kalpa therapy:}

- At the end of lasuna therapy a mild purgative should be administered, for the fear of increase of pitta. This helps to bestow the rejuvenator effects completely. Drinking uncooked water, use of products of sugarcane, fish, riding on animals, walking long distances, exposure to breeze, and sunlight, too much of speech, worry, sleeping during day, keeping awake at night, eating food prepared from flour, copulation and use of curds should be avoided during lasuna therapy.

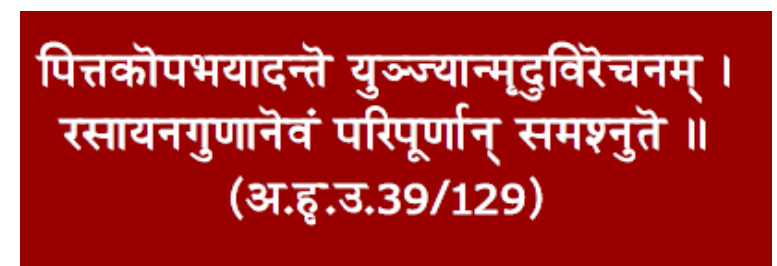

- This (rasona) should be avoided in diseases such as anemia, enlargement of the abdomen, injury to chest (lungs), dropsy, thirst, alcoholic intoxication vomiting, poison, wounds, diseases of pitta origin, eye disease, diarrhea and emaciation of the body. 


\section{RASAYANA PRAYOGA:}

- Lasuna kalka: Grind the dehusked tubers of rasona into kalka( paste) . Consume 1 pala (40gm) of this paste mixed with ghee $(80 \mathrm{gm}) \&$ little honey. Take milk \& rice as food after having the recipe. By taking this recipe of rasona, the person will achieve longevity\& disease free ageing. (Kasyapa samhita, kalpa sthana, 2/89-90)

- Lasuna ksira paka:Take dehusked lasuna bulbs, pound it \& make into kalka(paste).Take $10-15 \mathrm{gm}$ of this paste \& add with $100 \mathrm{ml}$ milk, $400 \mathrm{ml}$ water \& boil until it reduces to $100 \mathrm{ml}$ in total. Then filter it \& consume it. This recipe slows the process of ageing and cures diseases like udavarta(reverse peristalsis), grdhrasi(sciatica), hrdroga(cardiovascular diseases), vidradhi(abcess), sosa(emanciation), visamajvara(irregular fever) (Astanga Samgraha, Chikitsa sthana, 16/16)

Facts About Lasuna Regarding Rasayana Therapy

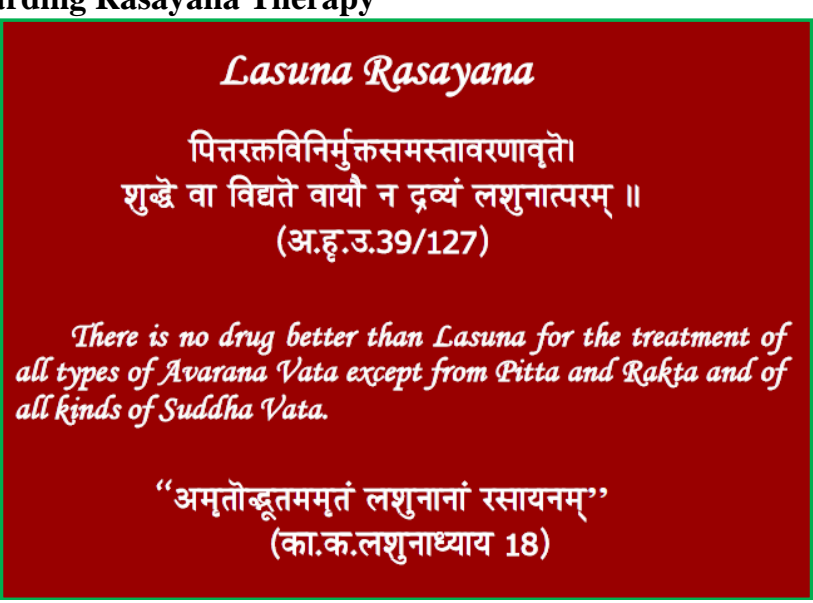

\section{This nectar Lasuna 6orm from nectar is Rasayana}

\section{Time of Administration}

\section{सभक्त / प्राग्भक्त}

\section{Lasuna Shresfitatha}


Acarya says,

साक्षादमृत सम्भूतेग्रार्मणीः स रसायनम् ॥",

(अ.हु.उ.39/111-112)

Rafu stole the nectar obtained 6y chuming the sea and swallowed it, he was immediately befieaded by god Vishnu, thus the drops of nectar fell over earth and became Lasuna, since it is 6orm from the 6ody of Rakshasa, the Brafimanas do not eat it. Since it is 6orn out of nectar, it is a best Rasayana.

शीलयैल्लशुनं शींते, वसन्तेरपि कफोल्वणः। घनोदयेगपि वातार्तः, सदा वा ग्रीष्मलीलया ॥ स्निग्धशुद्धतनुः शीतमधुरोपस्कुताशयः। तदुत्तंसावतंसाभ्यां चर्चितानुचराजिरः ॥ (अ.हु.उ.39/113-114)

\section{Prayoga Kala Maryada}

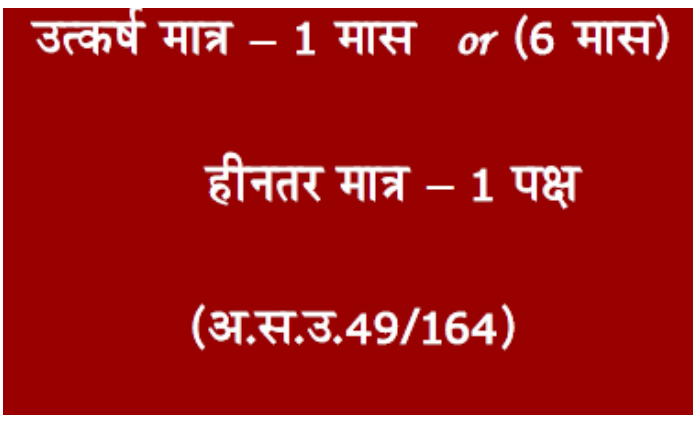

Prayoga Matra 


$$
\begin{aligned}
& \text { स्वरस + मदिर }-1 \text { कुडव } \\
& \text { केवल मात्र (स्वरस) }-1 / 2 \text { कुडव } \\
& \text { लशुन मज्जा मात्र }-1 \text { पल }
\end{aligned}
$$

$$
\text { (अ.हृ.उ.39/122) }
$$

According to Kasfiyapa

चतुष्पली भवेन्मात्रा लशुनानां कनीयसी ।

षट्पली मध्यमा, श्रेष्ठा पलाष्टौ च दशाथ वा ॥

$$
\begin{aligned}
& \text { कनीयसी मात्र : चतुष्पल } \\
& \text { मध्यम मात्र : षट्पल } \\
& \text { श्रेष्ठ मात्र : अष्ट पल, दश पल }
\end{aligned}
$$

\section{Numerical Dose of Lasuna}

According to Kasfiyapa

शतं षष्टिः शतार्ध च मात्राः स्युर्गणितेष्वपि ॥

$$
\begin{aligned}
& \text { उत्तम - } 100 \\
& \text { मध्यम - } 60 \\
& \text { अवर - } 50
\end{aligned}
$$




\section{Management after consumption of Lasuna}

Vedana: Pratatam Swedana.

Moorcha, Chardhi: Sheetham6u seka over Mukfia.

Daha: Sheeta Anulepana etc.

\section{Method of Administration}

\section{रसौउग्नि कल्पो मुदुनौजसा हि संयुप्यमानः सहसैव तस्य । दाहातिसारारति चित्तनाशान् कुर्यादतस्तं त्वरितो न युज्ज्यात् ॥ (अ.सं.उ.49/175)}

\begin{tabular}{cccc} 
Common Prescription frequently practiced 6y many For & \multicolumn{3}{c}{28 days } \\
Days & Swarasa & Anupana & Total \\
$1^{\text {st }}$ Week & $12 \mathrm{ml}$ & $36 \mathrm{ml}$ & $48 \mathrm{ml}$ \\
$2^{\text {nd } \text { Week }}$ & $24 \mathrm{ml}$ & $24 \mathrm{ml}$ & $48 \mathrm{ml}$ \\
$3^{\text {rd } \text { Week }}$ & $36 \mathrm{ml}$ & $12 \mathrm{ml}$ & $48 \mathrm{ml}$ \\
$4^{\text {th }}$ Week & $48 \mathrm{ml}$ & - & $48 \mathrm{ml}$
\end{tabular}




\section{For 16 Days}

Day

$$
\text { 1-4 Days ～5-8 Days 9-12 Days 13-16 Days }
$$

Casuna

$25 g m$

$50 \mathrm{gm}$

$75 g m$

$100 \mathrm{gm}$

Anupana

$75 \mathrm{ml}$

$50 m l$

$25 m l$

For 8 days

Day 1-2 Days 3-4 Days 5-6 Days 7-8 Days

Lasuna

$25 g m$

$50 \mathrm{gm}$

$75 \mathrm{gm}$

$100 g m$

Anupana

$75 m l$

$50 m l$

$25 m l$

We are what we eat, the common substance we eat and drink for example Water, Meat, Vegetables, Sugar etc., produce energy to sustain life. But Rasayana help us to lead healt fy Gfe. There are many other Rasayana's explained in our classics which has to be adopted and in this regard therapeutic utilization of Lasuna Rasayana is just the 6eginning.

VAJEEKARANA ROLE OF LASUNA- Ref. Kasya .kalpa .lasuna kalpa

- In females lasuna reduces the diseases which are occur due to coitus \& they never got PELVIC INFLAMMATORY DISORDERS.

- It produces Veerya \& Santhana in Napumsaka, Vandya,\& Vridda with ghritha prepared with Deepaniya, JeevaniyA, Dasamoolas. 
- Females don't attain vandya if they consume lasuna.

- "Asranthogramyadarmena", Sukradascha properties attain by male if he consumes lasuna regularly.

- Nilotpala, Padmavarna Garbha definitely attained by all females who ever participate in coitus by a single person who consumed lasuna.

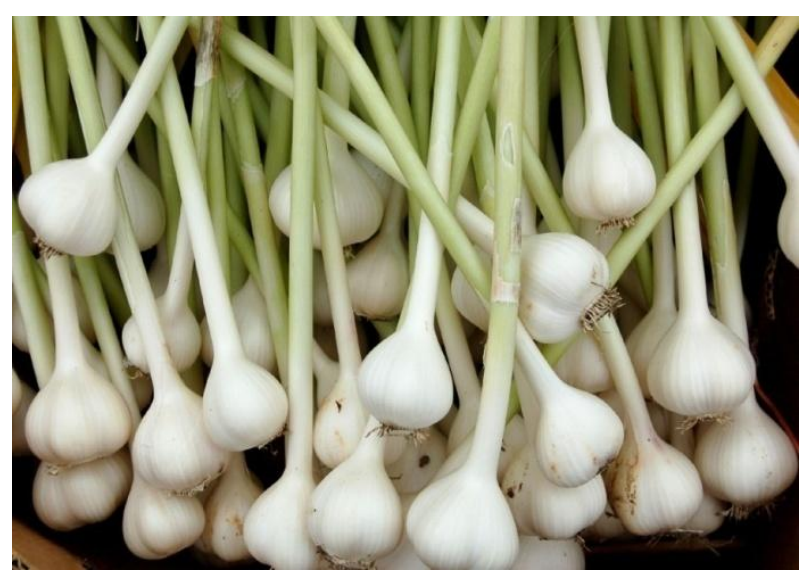

